Jurnal Akuntansi dan Manajemen

Vol.12, No.2, 2017, Hal. 24-50

\title{
PENGARUH KOMPETENSI SUMBER DAYA MANUSIA DAN TEKANAN EKSTERNAL TERHADAP KUALITAS LAPORAN KEUANGAN PEMERINTAH DAERAH STUDI KASUS PADA DINAS PENDAPATAN PENGELOLA KEUANGAN DAN ASET DAERAH KOTA SAWAHLUNTO
}

Rinka Merantika'), Randy Heriyanto')

Jurusan Akuntansi, Politeknik Negeri Padang

Email: rinka.merantika@gmail.com ${ }^{1)}$, heriyantorandy@gmail.com ${ }^{2}$ )

\begin{abstract}
This study aims to determine the effect of human resource competencies and external pressure on the quality of financial statements. Research uses a quantitative approach. Data collection of this study uses questionnaire surveys. Questionnaires were submitted to 52 Revenue Service Officers of Regional Finance and Asset Management (DPPKAD) of Sawahlunto City who were Civil Servants (PNS), as many as 48 questionnaires (92\%) were returned fully and could be processed. The collected power is processed using a smart PLS 2.0 program. Data analysis using the measurement model (outer model) and structural model (inner model), first carried out the Successive Interval Method (MSI). The results showed that the competence of human resources and external pressure had a positive effect on the quality of financial statements. Suggestions for further research are expected to expand the object of research and add other variables not included in this study.
\end{abstract}

Keywords: Quality of financial statements, HR competencies, external pressure.

\section{ABSTRAK}

Penelitian ini bertujuan untuk mengetahui pengaruh kompetensi sumber daya manusia dan tekanan eksternal terhadap kualitas laporan keuangan. Penelitian menggunakan pendekatan kuantitatif. Pengumpulan data penelitian ini menggunakan survei kuisioner. Kuisioner disampaikan kepada 52 pegawai Dinas Pendapatan Pengelola Keuangan dan Aset Daerah (DPPKAD) Kota Sawahlunto yang berstatus Pegawai Negeri Sipil (PNS), sebanyak 48 kuisioner (92\%) kembali diidi dengan lengkap dan dapat diolah. Daya yang dikumpulkan diolah dengan menggunakan program smart PLS 2.0. Analisis data menggunakan model pengukuran (outer model) dan model structural (inner model), terlebih dahulu dilakukan Metode Suksesif Interval (MSI). Hasil penelitian menunjukkan bahwa kompetensi sumber daya manusia dan tekanan eksternal berpengaruh positif terhadap kualitas laporan keuangan. Saran untuk penelitian selanjutnya diharapkan dapat memperluas objek penelitian dan menambahkan variabel lain yang belum termasuk dalam penelitian ini.

Kata kunci: Kualitas laporan keuangan, kompetensi SDM, tekanan eksternal.

\section{PENDAHULUAN}

Perubahan sistem politik, sosial dan kemasyarakatan serta ekonomi yang dibawa oleh arus reformasi telah menimbulkan tuntutan yang beragam terhadap pengelolaan pemerintahan yang baik (Good Government Governance). Otonomi daerah adalah salah satu bagian dari reformasi, dimana salah satu fenomena yang terjadi dalam perkembangan otonomi daerah adalah tingginya respon rakyat terhadap Good Government Governance. Hal ini dibuktikan dengan adanya tuntutan masyarakat terhadap peningkatan kualitas pengelolaan keuangan pemerintah. Otonomi daerah merupakan suatu pemberian hak dan wewenang dari pemerintah pusat kepada pemerintah daerah. Dalam otonomi daerah ada beberapa kebijakan dari pemerintah 
pusat yang diubah menjadi kebijakan pemerintah daerah. Salah satu dari kebijakan tersebut adalah pengelolaan keuangan daerah.

Otonomi daerah berawal pada tanggal 1 Januari 2001 melalui Undang-undang No.2 Tahun 1999 yang direvisi dengan Undang-undang No.32 Tahun 2004 tentang Pemerintah Daerah. Sedangkan reformasi aspek keuangan negara baik di pemerintah pusat maupun di pemerintah daerah telah berlaku sejak dikeluarkannya Undangundang No.25 Tahun 1999 dan telah direvisi dengan Undang-undang No.33 Tahun 2004 tentang Perimbangan Keuangan Pemerintah Pusat dan Pemerintah Daerah. Selanjutnya reformasi pengelolaan keuangan negara diatur dalam Undang-undang No.17 tahun 2003 tentang Keuangan Negara.

Laporan keuangan merupakan bentuk pertanggungjawaban pemerintah terhadap publik. Laporan keuangan disusun untuk menyediakan informasi yang relevan mengenai posisi keuangan dan seluruh transaksi yang dilakukan oleh suatu entitas. Laporan keuangan di dalam pemerintahan berguna untuk mengetahui nilai sumber daya ekonomi yang dimanfaatkan untuk melaksanakan kegiatan operasional pemerintahan, menilai kondisi keuangan, mengevaluasi efektivitas serta sebagai dasar dalam pembuatan keputusan oleh para pengguna laporan keuangan (Peraturan Pemerintah Republik Indonesia Nomor 71 tahun 2010).

Pemerintah daerah harus mampu menyajikan laporan keuangan yang mengandung informasi keuangan yang berkualitas. Karakteristik kualitatif laporan keuangan adalah ukuran-ukuran normatif yang perlu diwujudkan dalam informasi akuntansi sehingga dapat memenuhi suatu tujuan. Dalam Peraturan Standar Akuntansi Pemerintahan (PSAP) yang terdapat dalam PP 71 tahun 2010 menjelaskan bahwa suatu laporan keuangan yang berkualitas harus memenuhi beberapa karakteristik yaitu relevan, andal, dapat dibandingkan serta dapat dipahami (Peraturan Pemerintah Republik Indonesia Nomor 71 Tahun 2010).

Dalam pengelolaan keuangan yang baik, satuan kerja perangkat daerah (SKPD) harus memiliki sumber daya manusia yang kompeten, yang didukung dengan latar belakang pendidikan akuntansi, sering mengikuti pendidikan dan pelatihan, serta mempunyai pengalaman di bidang keuangan. Adanya sumber daya manusia yang kompeten akan mampu memahami logika akuntansi dengan baik. Kegagalan sumber daya manusia pemerintah daerah dalam memahami dan menerapkan logika akuntansi akan berdampak pada kekeliruan laporan keuangan yang dibuat dan ketidaksesuaian laporan dengan standar yang ditetapkan pemerintah (Warisno, 2008 dalam Windiastuti, 2013).

Pendidikan adalah salah satu upaya dalam mengembangkan sumber daya manusia terutama dalam pengembangan aspek intelektual dan kepribadian manusia. Pendidikan formal merupakan jalur pendidikan yang terstruktur dan berjenjang yang terdiri atas pendidikan anak usia dini, pendidikan dasar, pendidikan menengah, dan pendidikan tinggi. Tingkat pendidikan sering kali menjadi indikator yang menunjukkan derajat intelektualitas seseorang. Semakin tinggi tingkat pendidikan seseorang, maka semakin tinggi tingkat pengetahuan dan tingkat intelektualitas seseorang. Dengan tingkat pendidikan yang memadai seseorang lebih mudah dalam menjalankan tugasnya. Dalam pengelolaan keuangan daerah yang baik SKPD harus memiliki sumber daya manusia yang kompeten dengan latar belakang pendidikan akuntansi atau keuangan (Windiastuti, 2013).

Pendidikan dan pelatihan juga merupakan salah satu indikator dalam menciptakan sumber daya manusia yang kompeten. Program pendidikan dan pelatihan dilakukan untuk mengembangkan dan meningkatkan pengetahuan, 
keterampilan dan kemampuan pegawai yang sudah dimiliki agar kemampuan pegawai semakin baik. Dalam pengelolaan keuangan daerah yang baik, program pendidikan dan pelatihan bagi pegawai di suatu instansi pemerintahan memiliki peranan yang cukup penting, karena untuk menghasilkan laporan keuangan daerah yang baik dibutuhkan pegawai yang benar-benar memahami cara dan proses dalam penyusunan laporan keuangan daerah.

Pengalaman kerja dalam suatu organisasi juga menjadi salah satu indicator bahwa seseorang telah memiliki kemampuan yang lebih. Semakin lama pegawai bekerja dalam suatu bidang di organisasi, maka semakin banyak pengalaman pegawai tersebut dan semakin memahami apa yang menjadi tugas dan tanggungjawab yang diberikan kepada pegawai tersebut. Begitupun dalam penyusunan laporan keuangan daerah, SKPD diharapkan memiliki sumber daya manusia yang telah memiliki pengalaman kerja yang lebih lama di bidang akuntansi atau keuangan, karena dalam menyusun laporan keuangan dibutuhkan pegawai yang benar-benar memahami akuntansi atau keuangan serta aturan-aturan dalam penyusunan laporan keuangan daerah.

Tekanan eksternal juga merupakan salah satu faktor yang mempengaruhi kualitas laporan keuangan. Sentot Imam Wahjono (2010:208) dalam Budiawan (2014) mengemukakan bahwa kekuasaan seseorang bersumber dari penghargaan (reward), kekuasaan memaksa (coersive power), pengakuan hukum (legitimate power), keahlian (expert power), dan keteladanan seseorang (referent power) yang digunakan untuk mempengaruhi sebagai usaha untuk menciptakan komitmen (commitment), kepatuhan (compliance), dan perlawanan (resistance). Kekuatan koersif (coersive power) adalah tekanan eksternal yang diberikan oleh pemerintah, peraturan, atau lembaga lain untuk mengadopsi struktur atau sistem (Ashwort, 2009). Menurut Gibson et al (2012) dalam Halmawati dan Mustin (2015) tekanan merupakan dorongan yang dapat bersifat mendukung atau pun menolak pelaksanaan sebuah tanggung jawab ataupun kebijakan dalam sebuah organisasi. Tekanan ekternal pada organisasi pemerintahan yang sangat berpengaruh adalah tekanan yang diberikan oleh pemerintah itu sendiri, peraturan atau lembaga lain. Peraturan yang diberikan oleh pemerintah digunakan untuk mengatur praktik yang telah ada menjadi lebih baik (Ashworth, 2009 dalam Ridha dan Basuki, 2012).

Laporan Keuangan Pemerintah Daerah (LKPD) setiap tahunnya mendapat penilaian berupa opini dari Badan Pengawas Keuangan (BPK). Adapun opini yang diberikan oleh BPK adalah opini Wajar Tanpa Pengecualian (WTP), opini Wajar Dengan Pengecualian (WTP), opini Tidak Wajar (TP), dan opini Tidak Memberikan Pendapat (TMP).

Pemerintah Kota Sawahlunto telah mengukir sejarah baru dalam pengelolaan laporan keuangan daerah. Penantian panjang yang dilakukan selama tiga belas tahun akhirnya memberikan prestasi yang gemilang. Laporan Hasil Pemeriksaan Laporan Keuangan Pemerintah Daerah (LHP-LKPD) tahun anggaran 2015, Kota Sawahlunto mendapatkan opini tertinggi berupa Wajar Tanpa Pengecualian (WTP). Pada tahuntahun sebelumnya Pemerintah Daerah Kota Sawahlunto hanya mendapatkan opini Wajar Dengan Pengecualian (WDP). Hal ini menggambarkan adanya perbaikan sistem pengelolaan dan tanggung jawab dalam pencatatan dan pelaporan keuangan pemerintah daerah. Dengan mendapatkan LHP-LKPD dengan opini tertinggi artinya harapan seluruh masyarakat Kota Sawahlunto telah terkabul. Kepala BPK RI Perwakilan Sumatra barat menyatakan bahwa opini Wajar Tanpa Pengecualian 
tersebut diberikan berdasarkan kenyataan profesional yang didasarkan pada kesesuaian laporan keuangan dengan standar akuntansi (Padang Ekspres, 2016: 1).

Penelitian ini mengacu kepada penelitian terdahulu yang berkaitan dengan kualitas laporan keuangan, yaitu Sukmaningrum (2012), Windiastuti (2013), Surastiani dan Handayani (2015), Pradono dan Basukianto (2015), Ihsanti (2014); Purnamasari dan Handayani (2015), Syarifudin (2014), Wati, Herawati dan Sinarwati (2014), Nurillah (2014), Andini dan Yusrawati (2015) dan Ridha dan Basuki (2012). Berdasarkan hasil penelitian terdahulu, faktor-faktor yang mempengaruhi kualitas laporan keuangan masih menunjukan ketidakkonsistenan hasil. Sukmaningrum (2012) dan Syarifudin (2014) menyatakan bahwa kapasitas sumber daya manusia tidak berpengaruh signifikan terhadap kualitas laporan keuangan daerah. Purnamasari dan Handayani (2015) juga melakukan penelitian mengenai pengaruh SDM, Tekanan Eksternal, Komitmen Managemen terhadap transparansi Pelaporan Keuangan. Hasil penelitiannya menunjukkan bahwa pengaruh SDM tidak berpengaruh signifikan terhadap transparansi pelaporan keuangan. Namun penelitian yang dilakukan oleh Windiasatuti (2013), Ihsanti (2014), Nurillah (2014), Surastiani dan Handayani (2015), Andini dan Yusrawati (2015), Pradono dan Basukianto (2015) serta Wati dkk (2014) menyatakan bahwa Kompetensi Sumber Daya Manusia berpengaruh signifikan terhadap kualitas laporan keuangan.

Dalam penelitian yang dilakukan oleh Ridha dan Basuki (2012) menyatakan bahwa tekanan eksternal dan komitmen manajemen berpengaruh signifikan terhadap penerapan transparansi pelaporan keuangan. Selanjutnya penelitian yang dilakukan oleh Purnamasari dan Handayani (2015) juga menyatakan bahwa tekanan eksternal berpengaruh signifikan terhadap transparansi laporan keuangan.

Penelitian ini merujuk pada penelitian sebelumnya yang dilakukan oleh Windiastuti (2013) dengan judul penelitian "Pengaruh Sumber Daya Manusia Bidang Akuntansi dan Sistem Pengendalian Internal terhadap Kualitas Laporan Keuangan Pemerintah Daerah". Perbedaan penelitian ini terletak pada penambahan variabel tekanan eksternal dan tidak menggunakan variabel sistem pengendalian internal. Perbedaan lainnya adalah lokasi dan waktu penelitian. Penelitian ini dilakukan di DPPKAD Kota Sawahlunto.

Penelitian ini juga merujuk kepada penelitian yang dilakukan oleh Ridha dan Basuki (2012) dengan judul penelitian "Pengaruh Tekanan Eksternal, Ketidakpastian Lingkungan, dan Komitmen Managemen terhadap Penerapan Transparansi Pelaporan Keuangan". Perbedaan penelitian ini dengan penelitian yang Penulis lakukan yaitu Penulis menguji pengaruh tekanan eksternal terhadap kualitas laporan keuangan, sedangkan penelitian terdahulu menguji tekanan eksternal terhadap pelaporan transparansi pelaporan keuangan.

Berdasarkan fenomena yang diuraikan diatas, penelitian ini menjadipertimbangan penulis untuk meneliti masalah sumber daya manusia yang kompeten, yang didukung dengan latar belakang pendidikan akuntansi, sering mengikuti pendidikan dan pelatihan, serta mempunyai pengalaman di bidang keuangan dan tekanan eksternal terhadap kualitas laporan keuangan pemerintah daerah melalui penelitian yang berjudul "Pengaruh Kompetensi Sumber Daya Manusia dan Tekanan Eksternal terhadap Kualitas Laporan Keuangan Pemerintah Daerah (Studi Kasus Pada Dinas Pendapatan, Pengelolaan Keuangan dan Aset Daerah Kota Sawahlunto)". 


\section{TINJAUAN PUSTAKA DAN PERUMUSAN HIPOTESIS TINJAUAN PUSTAKA \\ Kompetensi Sumber Daya Manusia}

Kompetensi adalah perpaduan pengetahuan, keterampilan, sikap dan karakteristik pribadi lainnya yang diperlukan untuk mencapai keberhasilan dalam sebuah pekerjaan yang bisa diukur dengan menggunakan standar yang telah disepakati dan dapat ditingkatkan dengan pelatihan dan pengembangan (Marwansyah, 2014:36). Kompetensi menurut Spencer (1993:9) dalam Syarifudin (2014) yaitu suatu karakteristik yang mendasari kepribadian seseorang yang menyebabkan saling berkaitan dengan kriteria keprilakuan efektif dan kinerja yang unggul dalam pekerjaan atau situasi tertentu. Sumber daya manusia merupakan orang-orang dalam organisasi untuk mencapai tujuan organisasi. Amirudin (2009) dalam Windiastuti (2013) mengatakan Sumber Daya Manusia merupakan kemampuan dari anggota eksekutif maupun legislatif dalam menjalankan fungsi dan perannya masing-masing dalam pengelolaan keuangan daerah. Pengertian kompetensi sumber daya manusia menurut Ihsanti (2014) adalah kemampuan seseorang atau individu suatu organisasi (kelembagaan) atau suatu sistem untuk melaksanakan fungsi-fungsi atau kewenangan untuk mencapai tujuannya secara efektif dan efisien.

Keberhasilan suatu organisasi dalam mencapai suatu tujuan sangat ditentukan oleh kualitas dan kemampuan sumber daya manusia (SDM) yang berada di dalamnya. Dalam organisasi publik, peran SDM lebih ditekankan pada kemampuan memberikan pelayanan yang terbaik bagi masyarakat, sehingga organisasi tetap memiliki reputasi kinerja yang unggul dan akuntabel dimata masyarakat. Oleh karena itu, kompetensi SDM pada setiap level manajemen menjadi urgen baik level pimpinan maupun staf pemerintahan.

Martindas (2002:89) dalam Windiastuti (2013) mengatakan sumber daya manusia adalah satu kesatuan tenaga kerja manusia yang dalam organisasi dan bukan hanya sekedar penjumlahan karyawan-karyawan yang ada. Sebagai kesatuan, sumber daya manusia harus dipandang sebagai suatu sistem dimana tiap-tiap karyawan berfungsi untuk mencapai tujuan organisasi. Sumber daya manusia diukur berdasarkan latar belakang pendidikan yang diperoleh pegawai.

Warisno (2008:48) dalam Windiastuti (2013) mengatakan dalam pengelolaan keuangan daerah yang baik, SKPD harus memiliki sumber daya manusia yang kompeten, yang didukung dengan latar belakang pendidikan akuntansi, sering mengikuti pendidikan dan pelatihan dan mempunyai pengalaman di bidang keuangan. Sumber daya manusia yang kompeten tersebut akan mampu memahami logika akuntansi dengan baik. Kegagalan sumber daya manusia pemerintah daerah dalam memahami dan menerapkan logika akuntansi akan berdampak pada kekeliruan laporan keuangan yang dibuat dan ketidaksesuaian laporan dengan standar yang ditetapkan pemerintah. Kompetensi sumber daya manusia didukung oleh komponen berikut:

1. Latar Belakang Pendidikan

Pendidikan adalah segala upaya yang direncanakan untuk mempengaruhi orang lain baik individu, kelompok atau masyarakat sehingga mereka melakukan apa yang diharapkan oleh pelaku pendidikan (Soekidjo Notoatmodjo. 2003:16). Pendidikan juga merupakan proses pengubahan sikap dan tatalaku seseorang atau kelompok orang dalam usaha mendewasakan mendewasakan manusia melalui upaya pengajaran dan pelatihan, proses, cara, perbuatan mendidik (Pusat Bahasa Departemen Pendidikan Nasional, 
2002:263). Menurut UU RI No.20 Tahun 2003 tentang Sistem Pendidikan Nasional pasal 1 mendefenisikan pendidikan sebagai usaha sadar dan terencana untuk mewujudkan suasana belajar dan proses pembelajaran agar pesert didik secara aktif mengembangkan potensi dirinya untuk memiliki kekuatan spritual keagamaan, pengendalian diri, kepribadian, kecerdasan, akhlak mulia serta keterampilan yang diperlukan dirinya, masyarakat, bangsa dan negara.

Pendidikan merupakan upaya untuk mengembangkan sumber daya manusia terutama untuk pengembangan aspek intelektual dan kepribadian manusia. Pendidikan formal merupakan jalur pendidikan yang terstruktur dan berjenjang yang terdiri atas pendidikan anak usia dini, pendidikan dasar, pendidikan menengah dan pendidikan tinggi. Pendidikan formal dalam organisasi merupakan suatu proses pengembangan kemampuan ke arah yang diinginkan. Tingkat pendidikan seringkali menjadi indikator yang menunjukan derajat intelektual seseorang. Semakin tinggi tingkat pendidikan maka semakin tinggi pengetahuan dan tingkat intelektualitas seseorang. Dengan tingkat pendidikan yang memadai seseorang lebih mudah menjalankan tugasnya. Dalam pengelolaan keuangan daerah yang baik SKPD harus memiliki sumber daya manusia yang kompeten dengan dilatar belakangi pendidikan akuntansi atau keuangan.

2. Pendidikan dan Pelatihan

Menurut Wijaya (1970:75) pendidikan merupakan proses pengembangan dan pembinaan kemampuan pegawai dan meningkatkan kemampuan mengeluarkan gagasan sehingga mereka dapat menunaikan tugas kewajiban dengan sebaik-baiknya. Sedangkan pelatihan merupakan pengembangan keterampilan teknis sehingga pegawai dapat menjalankan pekerjaan dengan sebaik-baiknya. Sondang P. Siagian (1983:180) mendefenisikan pendidikan adalah keseluruhan proses, teknik dan metode mengajar dalam rangka mengalihkan sesuatu pengetahuan dari seseorang kepada orang lain dengan standar yang telah ditetapkan sebelumnya. Sedangkan pelatihan merupakan proses belajar dengan menggunakan teknik dan metode tertentu.

Program pendidikan dan pelatihan dilakukan untuk mengembangkan dan meningkatkan pengetahuan, keterampilan dan kemampuan pegawai yang sudah dimiliki agar kemampuan pegawai semakin baik. Pendidikan ditekankan pada peningkatan pengetahuan untuk melakukan pekerjaan pada masa yang akan datang, yang dilakukan melalui pendekatan yang terintegrasi dengan kegiatan lain untuk mengubah perilaku kerja, sedangkan pelatihan lebih ditekankan pada peningkatan kemampuan untuk melakukan pekerjaan yang spesifik pada saat ini.

Beberapa tujuan dari program pendidikan dan pelatihan pegawai diantaranya sebagai berikut:

a. Meningkatkan produktivitas kerja,

b. Meningkatkan kecakapan manajerial pegawai,

c. Menigkatkan efisiensi tenaga dan waktu,

d. Mengurangi tingkat kesalahan pegawai,

e. Menigkatkan pelayanan yang lebih baik dari karywan untuk konsumen perusahaan atau organisasi,

f. Menjaga moral pegawai, 
g. Meningkatkan karir pegawai.

Program pendidikan dan pelatihan sumber daya manusia memberikan dampak yang baik terhadap kinerja pegawai tersebut sebagai individu. Hal ini jelas akan membawa peningkatan terhadap kinerja organisasi apabila pelatihan dan pengembangan pegawai dilakukan secara terencana dan berkesinambungan. Dalam pengelolaan keuangan daerah yang baik, program pendidikan dan pelatihan bagi pegawai instansi pemerintah pun cukup penting, karena untuk menghasilkan laporan keuangan daerah yang baik dibutuhkan pegawai yang benar-benarmemahami cara dan proses penyusunan laporan keuangan daerah.

3. Pengalaman Kerja

Siagian (2002:62) dalam Windiastuti (2013) mengemukakan bahwa pengertian pengalaman langsung adalah ketika seseorang pernah bekerja pada suatu organisasi, lalu oleh karena sesuatu meninggalkan organisasi dan pindah ke organisasi yang lain. Sedangkan pengalaman tidak langsung adalah peristiwa yang diamati dan diikuti oleh seseorang pada suatu organisasi meskipun yang bersangkutan sendiri tidak menjadi anggota dari pada organisasi dimana peristiwa yang diamati dan diikuti terjadi.

Pengalaman kerja di dalam suatu organisasi menjadi salah satu indikator bahwa seseorang telah memiliki kemampuan yang lebih. Semakin lama seorang pegawai bekerja dalam suatu bidang di organisasi maka semakin banyak pengalaman pegawai tersebut dan semakin memahami apa yang menjadi tugas dan tanggungjawab yang diberikan kepada pegawai tersebut. Begitupun dalam penyusunan laporan keuangan daerah, SKPD diharapkan memiliki sumber daya manusia yang telah memiliki pengalaman kerja yang lebih lama di bidang akuntansi atau keuangan, karena dalam menyusun laporan keuangan dibutuhkan pegawai yang benar-benar memahami akuntansi atau keuangan beserta aturan-aturan dalam penyusunan laporan keuangan daerah.

\section{Tekanan Eksternal}

Sentot Imam Wahjono (2010:208) dalam Budiman (2014) mengemukakan bahwa kekuasaan seseorang bersumber dari penghargaan (reward), kekuasaan memaksa (coersive power), pengakuan hukum (legitimate power), keahlian (expert power), dan keteladanan seseorang (referent power) yang digunakan untuk mempengaruhi sebagai usaha untuk menciptakan komitmen (commitment), kepatuhan (compliance), dan perlawanan (resistance). Kekuatan koersif (coersive power) adalah tekanan eksternal yang diberikan oleh pemerintah, peraturan, atau lembaga lain untuk mengadopsi struktur atau sistem (Ashwort, 2009). Menurut Gibson et al (2012) dalam Halmawati dan Mustin (2015) tekanan merupakan dorongan yang dapat bersifat mendukung atau pun menolak pelaksanaan sebuah tanggung jawab ataupun kebijakan dalam sebuah organisasi.

Tekanan internal berhubungan dengan sejumlah dorongan atau penolakan terhadap sejumlah kebijakan yang dijalankan di dalam sebuah perusahaan yang bersumber dari dalam organisasi, seperti tekanan dari manajer, dan stakeholder lainnya. Sedangkan tekanan eksternal merupakan dorongan atau penolakan untuk melaksanakan sebuah kebijakan yang berasa dari luar organisasi. Seperti dukungan atau penolakan dari masyarakat, maupun dorongan atau larangan dari Pemerintah dalam bentuk peraturan atau tatanan hukum dan norma yang berlaku di masyarakat. 
Tekanan eksternal yang sangat berpengaruh adalah tekanan yang diberikan oleh pemerintah, peraturan, atau lembaga lain untuk mengadopsi struktur atau system (Ashworth, 2009 dalam Ridha dan Basuki, 2012). Adanya peraturan ditujukan untuk mengatur praktik yang ada agar menjadi lebih baik. Perubahan organisasi yang lebih dipengaruhi politik akan mengakibatkan praktik-praktik yang terjadi dalam organisasi, khususnya terkait peningkatan kualitas laporan keuangan akan hanya bersifat formalitas yang ditujukan untuk memperoleh legitimasi. Tekanan ekternal membuat seluruh anggota organisasi melaksanakan proses kegiatan operasional dengan semestinya, proses tersebut dilakukan dengan lebih terbuka seperti menggunakan tenaga auditor ekternal yang bersifat independen, ketika proses tersebut berhasil dilaksanakan tentu proses peningkatan kualitas laporan keuangan mengalami peningkatan.

Ridha dan Basuki (2012) menyebutkan bahwa peraturan dan perundangundangan merupakan indikator adanya tekanan eksternal dalam bentuk koersif pada penyusunan laporan keuangan. Indikator tersebut adalah:

1. Perubahan peraturan / perundang undangan,

2. Tuntutan pemimpin,

3. Tuntutan masyarakat,

4. Pemberitaan media masa,

5. Perhatian lebih dari lembaga swadaya masyarakat,

6. Tuntutan komunitas bisnis.

\section{Kualitas Laporan Keuangan Pemerintah Daerah}

1. Pemeritah Daerah

Peraturan Pemerintah Nomor 58 Tahun 2005 Tentang Pengelolaan Keuangan Daerah mendefenisikan pemerintah daerah sebagai penyelenggara pemerintahan daerah menurut asas otonomi dan tugas pembantuan dengan prinsip otonomi seluas-luasnya dalam sistem dan prinsip Negara Kesatuan Republik Indonesia sebagaimana dimaksud dalam Undang-Undang Dasar 1945. Gubernur, Bupati atau Walikota, dan perangkat daerah merupakan unsur penyelenggara pemerintahan daerah. Hubungan wewenang antara pemerintah pusat dan pemerintah daerah provinsi, kabupaten, dan kota atau antara provinsi dan kabupaten dan kota, diatur undang-undang dengan memperhatikan kekhususan dan keragaman daerah. Hubungan keuangan, pelayanan umum, pemanfatan sumber daya alam dan sumber daya lainnya antara pemerintah pusat dan pemerintahan daerah diatur dan dilaksanakan secara adil dan selaras berdasarkan undang-undang.

Pemerintahan daerah adalah penyelenggaraan urusan pemerintahan oleh pemerintah daerah dan DPRD menurut asas otonomi dan tugas pembantuan dengan prinsip otonomi seluas-luasnya dalam sistem dan prinsip Negara Kesatuan Republik Indonesia sebagaimana dimaksud dalam UUD 1945. Penyelenggaraan fungsi pemerintahan daerah akan terlaksana secara optimal apabila penyelenggaraan urusan pemerintahan diikuti dengan pemberian sumber-sumber penerimaan yang cukup kepada daerah, dengan mengacu kepada undang-undang yang mengatur perimbangan keuangan antara pemerintah pusat dan pemerintahan daerah. Besarnya penerimaan daerah disesuaikan dan diselaraskan dengan pembagian kewenangan antara 
pemerintah Pusat dan daerah. Semua sumber keuangan yang melekat pada setiap urusan pemerintah yang diserahkan kepada daerah, akan menjadi sumber keuangan daerah.

Daerah diberikan hak untuk mendapatkan sumber keuangan, antara lain berupa kepastian tersedianya pendanaan dari pemerintah sesuai dengan urusan pemerintah yang diserahkan; kewenangan memungut, mendayagunakan pajak dan retribusi daerah, hak untuk mendapatkan bagi hasil dari sumber daya nasional yang berada di daerah dan dana perimbangan lainnya; hak untuk mengelola kekayaan daerah dan mendapatkan sumbersumber pendapatan lain yang sah serta sumber-sumber pembiayaan.

Di dalam Undang-undang yang mengatur keuangan negara, terdapat penegasan di bidang pengelolaan keuangan. Kekuasaan pengelolaan keuangan negara merupakan bagian dari kekuasaan pemerintahan yang dipegang oleh presiden. Presiden memberikan sebagian dari kewenangannya kepada gubernur/ bupati/ walikota selaku kepala pemerintah daerah untuk mengelola keuangan daerah dan mewakili pemerintah daerah dalam kepemilikan kekayaan daerah yang dipisahkan.

Ketentuan tersebut berimplikasi pada pengaturan pengelolaan keuangan daerah, yaitu bahwa kepala daerah (gubernur/ bupati/ walikota) adalah pemegang kekuasaan pengelolaan keuangan daerah dan bertanggungjawab atas pengelolaan keuangan daerah sebagai bagian dari kekuasaan pemerintahan daerah. Dalam melaksanakan kekuasaannya, kepala daerah melimpahkan sebagian atau seluruh kekuasaan keuangan daerah kepada para pejabat perangkat daerah. Dengan demikian pengaturan pengelolaan dan pertanggungjawaban keuangan daerah melekat dan menjadi satu dengan pengaturan pemerintahan daerah, yaitu dalam undang-undang mengenai pemerintahan daerah.

Berdasarkan Undang-undang No 33 Tahun 2004, sumber pendapatan daerah terdiri atas:

a. Pendapatan Asli Daerah (PAD), yang meliputi hasil pajak daerah, hasil retribusi daerah, hasil pengelolaan kekayaan daerah yang dipisahkan, dan lain- lain PAD yang sah,

b. Dana perimbangan yang meliputi Dana Bagi Hasil, Dana Alokasi Umum dan Dana Alokasi Khusus,

c. Dan lain-lain pendapatan daerah yang sah.

Dinas Pendapatan, Pengelolaan Keuangan dan Aset Daerah (DPPKAD) berfungsi sebagai pengelola keuangan daerah. Dinas Pendapatan, Pengelolaan Keuangan dan Aset Daerah memiliki Tugas Pokok melaksanakan urusan Pemerintah Daerah berdasarkan asas otonomi dan tugas pembantuan di bidang Pendapatan, Pengelolaan Keuangan dan Aset Daerah. Fungsi Dinas Pendapatan, Pengelolaan Keuangan dan Aset Daerah yaitu:

a. Perumusan kebijakan teknis di bidang Pendapatan, Pengelolaan Keuangan dan Aset Daerah,

b. Penyelenggaraan urusan pemerintahan dan pelayanan umum di bidang Pendapatan, Pengelolaan Keuangan dan Aset Daerah,

c. Pembinaan dan pelaksanaan tugas di bidang Pendapatan, Pengelolaan Keuangan dan Aset Daerah,

d. Pelaksanaan tugas lain yang diberikan oleh Kepala Daerah. 
2. Laporan Keuangan

Laporan keuangan adalah catatan informasi suatu entitas pada suatu periode akuntansi yang dapat digunakan untuk menggambarkan kinerja entitas tersebut. Laporan keuangan merupakan laporan yang terstruktur mengenai posisi keuangan dan transaksi-transaksi yang dilakukan oleh suatu entitas pelaporan. Laporan keuangan dapat dikatakan sebagai data, dan dapat juga dikatakan sebagai informasi. Data dapat berubah menjadi informasi jika diubah kedalam konteks yang memberikan makna (Lillrank, 2003) dalam Nurillah (2014).

Laporan keuangan pemerintah ditujukan untuk memenuhi tujuan umum pelaporan keuangan, namun tidak untuk memenuhi kebutuhan kusus pemakainya. Disamping penyusunan laporan keuangan keuangan bertujuan umum, entitas pelaporan dimungkinkan untuk menghasilkan laporan keuangan yang disusun untuk kebutuhan khusus. Mardiasmo (2002:160) dalam (Permadi 2013) mengatakan bahwa lembaga pemerintah dituntut untuk dapat membuat laporan keuangan eksternal yang meliputi laporan keuangan formal seperti laporan surplus defisit, laporan realisasi anggaran, laporan arus kas dan neraca serta kinerja yang dinyatakan dalam ukuran finansial dan non finansial.

Pengguna laporan keuangan pemerintahan menurut International Federation of Accountans-Public Sector Committee (IFAC-PSC)dalam Permadi (2013) dikelompokkan sebagai berikut:

a. Badan legislatif dan badan-badan lain yang memiliki kekuasaan untuk mengatur dan mengawasi kondisi keuangan Badan legislatif merupakan pengguna utama dari laporan keuangan pemerintah. Laporan keuangan tersebut akan memberikan informasi yang membantu untuk dapat mengetahui bagaimana pemerintah mengurus sumber- sumber, ketaatan terhadap ketentuan-ketentuan perundang-undangan, kondisi keuangan maupun kinerja.

b. Rakyat

Rakyat merupakan kelompok terbesar dari pengguna laporan, yang terdiri dari para pembayar pajak, pemilih, serta kelompok-kelompok yang mempunyai ketertarikan khusus dan memperoleh pelayanan dan manfaat dari pemerintah.

c. Investor dan kreditur

Pemerintah harus memberikan informasi-informasi yang berguna kepada investor dan kreditur pemerintah. Tujuannya adalah untuk memberikan penilaian terhadap kemampuan pemerintah dalam membiayai kegiatan kegiatan serta memenuhi kewajiban pada komitmennya.

d. Pemerintah lain, badan internasional, dan penyedia sumber lain

Seperti investor dan kreditur, bahwa pemerintah lain, badan internasional, dan penyedia sumber lain menaruh ketertarikan terhadap kondisi keuangan pemerintah. Selain itu mereka juga menaruh perhatian terhadap terhadap rencana-rencana dan kebijakan-kebijakan.

e. Analisis ekonomi dan keuangan

Para analisis ekonomi dan keuangan termasuk media-media keuangan menelaah, menganalisis dan menyebarkan hasil-hasilnya kepada para pemakai laporan yang lain. Tugas mereka adalah melakukan evaluasi masalah-masalah ekonomi dan keuangan. 
3. Tujuan Penyajian Laporan Keuangan Pemerintah Daerah

Tujuan umum laporan keuangan adalah menyajikan informasi mengenai posisi keuangan, realisasi anggaran, arus kas, dan kinerja keuangan suatu entitas pelaporan yang bermanfaat bagi para pengguna dalam membuat dan mengevaluasi keputusan mengenai alokasi sumber daya. Secara spesifik, tujuan pelaporan keuangan pemerintah adalah untuk menyajikan informasi yang berguna untuk pengambilan keputusan. Laporan keuangan untuk tujuan umum juga mempunyai peranan prediktif dan prospektif, menyediakan informasi yang berguna untuk memprediksi besarnya sumber daya yang dihasilkan untuk operasi yang berkelanjutan, serta risiko dan ketidakpastian yang terkait.

Informasi dalam laporan keuangan tersebut relevan untuk memenuhi tujuan laporan keuangan pemerintah, namun tidak dapat sepenuhnya memenuhi tujuan tersebut. Informasi tambahan, termasuk laporan non keuangan, dapat dilaporkan bersama-sama dengan laporan keuangan untuk memberikan gambaran yang lebih komprehensif mengenai aktivitas suatu entitas pelaporan selama satu periode.

4. Komponen Laporan Keuangan Pemerintah Daerah

Laporan keuangan berdasarkan Peraturan Pemerintah No.71 tahun 2010 tentang standar Akuntansi Pemerintahan terdiri dari:

a. Laporan Realisasi Anggaran (LRA)

Laporan realisasi anggran menyajikan ikhtisar sumber, lokasi, dan pemakaian sumber daya keuangan yang dikelola oleh pemerintah pusat/daerah yang menggambarkan perbandingan antara anggaran dan realisasinya dalam suatu periode pelaporan. Unsur yang dicakup secara langsung oleh laporan realisasi anggaran trdiri dari pendapatan-LRA, belanja, transfer, dan pembiayaan.

b. Laporan Perubahan Saldo Anggaran Lebih (Laporan Perubahan SAL)

Laporan Perubahan Saldo Anggaran Lebih menyajikan informasi kenaikan atau penurunan Saldo Anggaran Lebih tahun pelaporan yang dibandingkan dengan tahun sebelumnya.

c. Neraca

Neraca menggambarkan posisi keuangan suatu entitas pelaporan mengenai aset, kewajiban, dan ekuitas pada tanggal tertentu. Unsur yang dicakup oleh neraca terdiri dari aset, kewajiban, dan ekuitas. Aset merupakan sumber daya ekonomi yang dikuasai dan/atau dimiliki oleh pemerintah sebagai akibat dari peristiwa masa lalu dan dari mana manfaat ekonomi dan/atau sosial dimasa depan diharapkan dapat diperoleh, baik oleh pemerintah maupun masyarakat, serta dapat diukur dalam satuan uang termasuk sumber daya non keuangan yang diperlukan untuk penyediaan jasa bagi masyarakat umum dan sumber-sumber daya yang dipelihara karena alasan sejarah dan budaya. Kewajiban merupakan utang yang timbul dari peristiwa masa lalu yang penyeleseiannya mengakibatkan aliran keluar sumber daya ekonomi pemerintah. Ekuitas merupakan kekayaan bersih pemerintah yang merupakan selisih antara asset dan kewajiban pemerintah. 
d. Laporan Operasional (LO)

Laporan operasional menyajikan ikhtisar sumber daya ekonomi yang menambah ekuitas dan penggunaanya yang dikelola oleh pemerintah pusat/daerah untuk kegiatan penyelenggaraan pemerintahan dalam suatu periode pelaporan. Unsur yang dicakup secara langsung dalam laporan operasional terdiri dari pendapatan-LO, beban, transfer dan pos-pos luar biasa. Pendapatan-LO merupakan hak pemerintah yang diakui sebagai penambah nilai kekayaan bersih. Beban merupakan kewajiban pemerintah yang diakui sebagai pengurangan nilai kekayaan bersih. Transfer merupakan hak penerimaan atau kewajiban pengeluaran uang dari/oleh suatu entitas pelaporan dari/kepada entitas pelaporan lain, termasuk dana perimbangan dan dana bagi hasil. Pos luar biasa merupakan pendapatan luar biasa atau beban luar biasa yang terjadi karena kejadian atau transaksi yang bukan merupakan operasi biasa, tidak diharapkan sering atau rutin terjadi dan berada di luar kendali atau pengaruh entitas bersangkutan.

e. Laporan Arus Kas (LAK)

Laporan arus kas menyajikan informasi kas sehubungan dengan aktifitas operasi, investasi, pendanaan, dan transitoris yang menggambarkan saldo awal, penerimaan, pengeluaran, dan saldo akhir kas pemerintah pusat/daerah selama periode terentu. Unsur yang dicakup dalam laporan arus kas terdiri dari penerimaan dan pengeluaran kas. Penerimaan kas merupakan semua aliran kas yang masuk ke bendahara umum negara /daerah. Pengeluaran kas merupakan semua aliran kas yang keluar ke bendahara umum negara /daerah.

f. Laporan Perubahan Ekuitas (LPE)

Laporan Perubahan Ekuitas menyajikan informasi kenaikan atau penurunan ekuitas tahun pelaporan dibandingkan tahun sebelumnya.

g. Catatan Atas Laporan Keuangan (CALK)

Catatan Atas Laporan Keuangan meliputi penjelasan naratif atau rincian dari angka yang tertera dalam Laporan Realisasi Anggaran, Laporan Perubahan SAL, Laporan Operasional, Laporan Perubahan Ekuitas, Neraca dan Laporan Arus Kas. Catatan atas Laporan Keuangan juga mencakup informasi tentang kebijakan akuntansi yang dipergunakan oleh entitas pelaporan dan informasi lain yang diharuskan dan dianjurkan untuk diungkapkan di dalam Standar Akuntansi Pemerintahan serta ungkapanungkapan yang diperlukan untuk menghasilkan penyajian laporan keuangan secara wajar.

5. Karakteristik Kualitatif Laporan Keuangan Pemerintah Daerah

Karakteristik kualitatif laporan keuangan adalah ukuran-ukuran normatif yang perlu diwujudkan dalam informasi akuntansi sehingga dapat memenuhi tujuannya. Keempat karakteristik berikut merupakan prasyarat normatif yang diperlukan agar laporan keuangan pemerintah dapat memenuhi kualitas yang dikehendaki:

a. Relevan

Laporan keuangan dikatakan relevan jika informasi yang termuat didalamnya dapat mempengaruhi keputusan pengguna dalam membantu mereka mengevaluasi peristiwa masa lalu atau masa kini, dan memprediksi masa depan, serta menegaskan atau mengoreksi hasil 
evaluasi mereka dimasa lalu. Dengan demikian informasi laporan keuangan yang relevan dapat dihubngkan dengan maksud penggunaannya. Adapun informasi yang relevan, terdiri atas:

i. Memiliki manfaat umpan balik (feedback value)

Informasi memungkinkan pengguna untuk menegaskan atau mengoreksi ekspektasi mereka di masa lalu

ii. Memiliki manfaat prediktif (predictive value)

Informasi dapat membantu pengguna untuk memprediksi masa yang akan datang berdasarkan hasil masa lalu dan kejadian masa kini

iii. Tepat Waktu

Informasi disajikan tepat waktu sehingga dapat berpengaruh dan berguna dalam pengambilan keputusan

iv. Lengkap

Informasi akuntansi keuangan pemerintah disajikan selengkap mungkin, mencakup semua informasi akuntansi yang dapat mempengaruhi pengambilan keputusan dengan memperhatikan kendala yang ada. Informasi yang melatar belakangi setiap butir informasi utama yang termuat dalam laporan keuangan diungkapkan dengan jelas agar kekeliruan dalam penggunaan informasi tersebut dapat dicegah.

b. Andal

Informasi dalam laporan keuangan bebas dari pengertian yang menyesatkan dan kesalahan material, menyajikan fakta secara jujur, serta dapat diverifikasi. Informasi mungkin relevan, tetapi jika hakikat atau penyajiannya tidak dapat diandalkan maka penggunaan informasi tersebut secara potensial dapat menyesatkan. Informasi yang andal memenuhi karakteristik sebagai berikut:

i. Penyajian jujur

Informasi menggambarkan dengan jujur transaksi serta peristiwa lainnya yang seharusnya disajikan atau yang secara wajar dapat diharapkan untuk disajikan.

ii. Dapat Diverifikasi (verifiability)

Informasi yang disajikan dalam laporan keuangan dapat diuji, dan apabila pengujian dilakukan lebih dari sekali oleh pihak yang berbeda, hasilnya tetap menunjukan simpulan yang tidak berbeda jauh.

iii. Netralitas

Informasi diarahkan pada kebutuhan umum dan tidak berpihak pada kebutuhan pihak tertentu.

c. Dapat Dibandingkan

Informasi yang termuat dalam laporan keuangan akan lebih berguna jika dapat dibandingkan dengan laporan keuangan periode sebelumnya atau laporan keuangan entitas pelaporan lain pada umumnya. Perbandingan dapat dilakukan secara internal dan eksternal. Perbandingan secara internal dapat dilakukan bila suatu entitas menerapkan kebijakan akuntansi yang sama dari tahun ke tahun.

Perbandingan secara eksternal dapat dilakukan bila entitas yang diperbandingkan menerapkan kebijakan akuntansi yang sama. Apabila 
entitas pemerintah menerapkan kebijakan akuntansi yang lebih baik dari pada kebijakan akuntansi yang sekarang diterapkan, perubahan tersebut iungkapkan pada periode terjadinya perubahan.

d. Dapat Dipahami

Informasi yang disajikan dalam laporan keuangan dapat dipahami oleh pengguna dan dinyatakan dalam bentuk serta istilah yang disesuaikan dengan batas pemahaman para pengguna. Untuk itu pengguna diasumsikan memiliki pengetahuan yang memadai atas kegiatan dan lingkungan operasi entitas pelaporan, serta adanya kemauan pengguna untuk mempelajari informasi yang dimaksud.

6. Kendala Informasi yang Andal dan Relevan

Kendala informasi akuntansi dan laporan keuangan adalah setiap keadaan yang tidak memungkinkan terwujudnya kondisi yang ideal dalam mewujudkan informasi akuntansi dan laporan keuangan yang relevan dan andal akibat keterbatasan atau karena alasan-alasan kepraktisan. Tiga hal yang menimbulkan kendala dalam informasi akuntansi dan laporan keuangan pemerintah yaitu:

a. Materialitas

Walaupun idealnya memuat segala informasi, laporan keuangan pemerinta hanya diharuskan memuat informasi yang memenuhi kriteria materialitas Informasi dipandang material apabila kelalaian untuk mencantumkan atau kesalahan dalam mencatat informasi tersebut dapat mempengaruhi keputusan ekonomi pengguna yang diambil atas dasar laporan keuangan.

b. Pertimbangan biaya dan manfaat

Manfaat yang dihasilkan informasi seharusnya melebihi biaya penyusunannya. Oleh karena itu laporan keuangan pemerintah tidak semestinya menyajikan segala informasi yang manfaatnya lebih kecil dari biaya penyusunannya. Namum demikian evaluasi biaya dan manfaat merupakan proses pertimbangan yang subtansial. Biaya itu juga tidak harus dipikul oleh pengguna informasi yang menikmati manfaat. Manfaat mungkin juga dinikmati oleh pengguna lain disamping mereka yang menjadi tujuan informasi, misalnya penyediaan informasi lanjutan kepada kreditor mungkin akan mengurangi biaya yang dipikul oleh suatu entitas pelaporan.

c. Keseimbangan antar karakteristik kualitatif

Keseimbangan antar karakteristik kualitatif diperlukan untuk mencapai suatu keseimbangan yang tepat diantara berbagai tujuan normatif yang diharapkan dipenuhi oleh laporan keuangan pemerintah. Kepentingan relatif antar karakteristik dalam berbagai kasus berbeda, terutama antara relevansi dan keandalan. Penentuan tingkat kepentingan antara dua karakteristik kualitatif tersebut merupakan masalah pertimbangan profesional.

Kualitas laporan keuangan juga bisa dinilai dari hasil pemeriksaan yang dilakukan oleh BPK. Pemeriksaan keuangan adalah pemeriksaan atas Laporan Keuangan (LK) yang bertujuan memberikan keyakinan yang memadai (reasonable assurance) bahwa LK telah disajikan secara wajar dalam semua hal yang material, sesuai dengan prinsip akuntansi yang berlaku umum di Indonesia atau basis 
akuntansi komprehensif selain prinsip akuntansi yang berlaku umum di Indonesia. Pemeriksaan atas LK dilakukan dalam rangka memberikan pendapat/opini atas kewajaran informasi keuangan yang disajikan dalam laporan keuangan.

Terdapat empat jenis opini yang dapat diberikan oleh pemeriksa, yakni:

a. Wajar Tanpa Pengecualian (WTP) memuat suatu pernyataan bahwa laporan keuangan menyajikan secara wajar, dalam semua hal yang material sesuai dengan Standar Akuntansi Pemerintahan (SAP). Sesuai dengan Standar Profesional Akuntan Publik (SPAP) yang diberlakukan dalam Standar Pemeriksaan Keuangan Negara (SPKN), BPK dapat memberikan opini wajar tanpa pengecualian dengan paragraf penjelas (WTP-DPP) karena keadaan tertentu sehingga mengharuskan pemeriksa menambahkan suatu paragraph penjelasan dalam LHP sebagai modifikasi dari opini WTP.

b. Wajar Dengan Pengecualian (WDP) memuat suatu pernyataan bahwa laporan keuangan menyajikan secara wajar, dalam semua hal yang material sesuai dengan SAP, kecuali untuk dampak hal-hal yang berhubungan dengan yang dikecualikan.

c. Tidak Wajar (TW) memuat suatu pernyataan bahwa laporan keuangan tidak menyajikan secara wajar dalam semua hal yang material sesuai dengan SAP.

d. Pernyataan Menolak Memberikan Opini atau Tidak Memberikan Pendapat (TMP) menyatakan bahwa pemeriksa tidak menyatakan opini atas laporan keuangan.

\section{PERUMUSAN HIPOTESIS}

\section{Kompetensi Sumber Daya Manusia}

Dalam menghasilkan laporan keuangan daerah yang berkualitas dibutuhkan Sumber Daya Manusia (SDM) yang berkompeten dalam bidang akuntansi pemerintahan yang didukung oleh latar belakang pendidikan, pendidikan dan pelatihan serta pengalaman di bidang keuangan. Terbatasnya pegawai yang berlatar belakang pendidikan bidang akuntansi membuat kurangnya pemahaman aparatur Pemerintah Daerah dala mengelola keuangan daerah dengan baik dan benar. Keterbatasan SDM yang memahami mekanisme penyusunan Laporan Keuangan yang sesuai dengan Standar Akuntansi Pemerintahan juga menjadi kendala dalam mewujudkan Laporan Keuangan Pemerintah Daerah (LKPD) yang berkualitas. Seseorang yang memiliki kompetensi akan bekerja dengan pengetahuan dan ketrampilanya sehingga dapat bekerja dengan mudah, cepat, intuitif dan dengan pengalamanya bisa meminimalisir keSalahan.

Ada beberapa peneliti terdahulu yang melakukan penelitian yang berkaitan dengan kualitas laporan keuangan, yaitu Sukmaningrum (2012), Windiastuti (2013), Surastiani dan Handayani (2015), Pradono dan Basukianto (2015), Ihsanti (2014), Purnamasari dan Handayani (2015), Syarifudin (2014), Wati, dkk (2014), Nurillah (2014), Andini dan Yusrawati (2015)dan Ridha dan Basuki (2012). Berdasarkan hasil penelitian terdahulu, faktor-faktor yang mempengaruhi kualitas laporan keuangan masih menunjukan ketidakkonsistenan hasil. Sukmaningrum (2012) dan Syarifudin (2014) menyatakan bahwa kapasitas Sumber Daya Manusia Bidang Akuntansi tidak berpengaruh signifikan terhadap kualitas laporan keuangan daerah. Dewi (2015) juga melakukan penelitian mengenai pengaruh SDM, Tekanan Eksternal, Komitmen Managemen terhadap transparansi Pelaporan Keuangan. Hasil penelitiannya 
menunjukkan bahwa pengaruh SDM tidak berpengaruh signifikan terhadap transparansi pelaporan keuangan. Namun penelitian yang dilakukan oleh Windiasatuti (2013), Ihsanti (2014), Nurillah (2014), Surastiani dan Handayani (2015), Andini dan Yusrawati (2015), Pradono dan Basukianto (2015) serta Wati dkk (2014) menyatakan bahwa Sumber Daya Manusia Bidang Akuntansi berpengaruh signifikan terhadap kualitas laporan keuangan.

H1 : Kompetensi Sumber Daya Manusia berpengaruh positif terhadap Kualitas Laporan Keuangan Pemerintah Daerah

\section{Tekanan Eksternal}

Kekuatan koersif (coersive power) adalah tekanan eksternal yang diberikan oleh pemerintah, peraturan, atau lembaga lain untuk mengadopsi struktur atau system (Ashwort, 2009). Tekanan eksternal merupakan dorongan atau penolakan untuk melaksanakan sebuah kebijakan yang berasa dari luar organisasi, seperti dukungan atau penolakan dari masyarakat, maupun dorongan atau larangan dari pemerintah dalam bentuk peraturan atau tatanan hukum dan norma yang berlaku di masyarakat. Tekanan eksternal yang sangat berpengaruh adalah tekanan yang diberikan oleh pemerintah, peraturan, atau lembaga lain. Adanya peraturan ditujukan untuk mengatur praktik yang ada agar menjadi lebih baik. Tekanan ekternal membuat seluruh anggota organisasi melaksanakan proses kegiatan operasional dengan semestinya.

Ridha dan Basuki (2012) menyebutkan bahwa peraturan dan perundangundangan merupakan indikator adanya tekanan eksternal dalam bentuk koersif pada penyusunan laporan keuangan. Indikator tersebut adalah:

1. Perubahan peraturan / perundang undangan,

2. Tuntutan pemimpin,

3. Tuntutan masyarakat,

4. Pemberitaan media masa,

5. Perhatian lebih dari lembaga swadaya masyarakat,

6. Tuntutan komunitas bisnis.

Budiawan (2014) menyimpulkan bahwa sumber-sumber kekuatan koersif berasal dari:

1. Perubahan peraturan / perundang undangan,

2. Pemberian sanksi,

3. Tuntutan masyarakat,

4. Kontrol media masa,

5. Kontrol dunia bisnis,

6. Perkembangan teknologi dan informasi.

Dalam penelitian yang dilakukan oleh Ridha dan Basuki, (2012) menyatakan bahwa tekanan eksternal berpengaruh signifikan terhadap penerapan transparansi pelaporan keuangan. Hal ini diperkuat dengan penelitian yang dilakukan oleh (Purnamasari dan Handayani, 2015) juga menyatakan bahwa tekanan eksternal berpengaruh signifikan terhadap transparansi laporan keuangan. Perbedaan penelitian yang dilakukan oleh Ridha dan Basuki (2012) dan Purnamasari dan handayani (2015) dengan penelitian yang akan Penulis lakukan yaitu variabel dependen Penulis adalah kualitas laporan keuangan, sedangkan variabel dependen peneliti terdahulu adalah transparansi laporan keuangan.

Semakin banyak aturan dan tuntutan yang diberikan oleh pemerintah dan lembaga lainnya dalam pembuatan laporan keuangan, maka kualitas laporan 
keuangan yang dihasilkan akan semakin baik. Banyak tekanan yang diberikan kepada Pemerintah Daerah akan meningkatkan kehati-hatian serta keseriusan dalam meningkatkan kualitas laporan keuangan.

H2 : Tekanan Eksternal berpengaruh positif terhadap Kualitas laporan

Keuangan Pemerintah Daerah

\section{METODE PENELITIAN}

\section{Populasi dan Sampel Penelitian}

Indriantoro dan Supomo (2002:115) menyatakan bahwa populasi merupakan sekelompok orang, kejadian atau segala sesuatu yang mempunyai karakteristik tertentu. Sugiyono (2004:72) dalam Permadi (2013)juga mengungkapkan bahwa populasi merupakan suatu objek atau subjek yang mempunyai kualitas dan karakteristik tertentu yang ditetapkan oleh peneliti untuk dipelajari dan kemudian ditarik kesimpulannya. Populasi bukan sekedar jumlah yang ada pada objek dan subjek yang dipelajari namun meliputi seluruh karakteristik atau sifat yang dimiliki oleh subjek atau objek yang diteliti. Populasi dalam penelitian ini adalah Seluruh karyawan atau staff yang bekerja di DPPKAD Kota Sawahlunto yang berjumlah 63 orang.

Sampel menurut Sugiyono (2004:73) dalam (Permadi, 2013) yaitu bagian dari jumlah dan karakteristik yang dimiliki oleh populasi tersebut. Dalam penelitian ini teknik yang digunakan dalam penentuan sampel adalah teknik Non Probability Sampling. Teknik sampling nonprobabilitas adalah teknik pengambilan sampel yang ditentukan sendiri oleh peneliti atau berdasarkan pertimbangan pakar. Pengambilan sampel ini harus dilakukan sedemikian rupa sehingga dapat mewakili dan menggambarkan populasi yang sebenarnya. Berdasarkan populasi diatas peneliti melakukan penelitian kepada semua pegawai yang berstatus PNS yang berada di Dinas DPPKAD Kota sawahlunto yang berjumlah 52 orang.

\section{VARIABEL PENELITIAN}

\section{Variabel Dependen}

Variabel dependen sering kita sebut dengan variabel terikat. Variabel dependen adalah tipe variabel yang dipengaruhi oleh variabel independen. Variabel dependen dalam penelitian ini adalah Kualitas Laporan Keuangan.

\section{Variabel Independen}

Variabel independen sering kita kenal dengan variabel bebas. Variabel independen merupakan tipe variabel yang mempengaruhi variabel dependen (terikat), Indriantoro dan Supomo (2002:63). Variabel independen dari penelitian ini adalah Kompetensi Sumber Daya Manusia (X1), Tekanan Eksternal (X2).

\section{JENIS DAN SUMBER DATA}

Penelitian ini merupakan penelitian dengan jenis kuantitatif. Data yang digunakan adalah data primer yaitu data yang diperoleh dari kuisioner yang dibagikan dan telah

diisi oleh staff atau karyawan pada Dinas DPPKAD Kota Sawahlunto yang menjadi responden terpilih dalam penelitian ini. Metode pengumpulan data yang digunakan adalah survei langsung dengan memberikan kuisioner kepada staff atau karyawan DPPKAD Kota Sawahlunto. Skala pengukuran yang digunakan untuk variabel dalam penelitian ini adalah dengan menggunakan skala likert yaitu : 
1. Sangat tidak setuju,

2. Tidak setuju,

3. Kurang setuju,

4. Setuju,

5. Sangat setuju.

\section{METODE ANALISIS}

Pengolahan data dalam penelitian ini dilakukan dengan bantuan program computer Smart PLS 2. Analisis data menggunakan model pengukuran (outer model) dan model struktural (inner model). Hal ini digunakan untuk mengetahui bagaimana pengaruh antara variabel independen (Kompetensi Sumber Daya Manusia dan Tekanan Eksternal) dengan variabel dependen (Kualitas Laporan Keuangan).

\section{TENIK ANALISIS DATA \\ Statistik Deskriptif}

Sebelum melakukan analisis konstruk dan hipotesis, perlu dilakukan analisis statistik deskriptif. Hal ini dilakukan untuk dapat memahami, mendeskripsikan dan menerangkan data atau peristiwa yang dikumpulkan dalam suatu penelitian

\section{Partial Least Square (PLS)}

\section{Model Pengukuran atau Outer Model}

Model ini digunakan untuk mengetahui validitas dan reliabilitas dari indikator. Evaluasi model pengukuran ini bersifat reflektif. Untuk itu digunakan pengukuran berikut, yaitu:

\section{a.Convergent Validity}

Evaluasi Convergent validity dimulai dengan melihat item reliability (indicator validitas) yang ditunjukkan oleh nilai loading factor. Nilai loading factor kurang dari 0,5 akan dihilangkan dari dalam model. Pemeriksaan selanjutnya dari convergent validity adalah dengan melihat nilai Average Variance Extracted (AVE). Nilai AVE untuk setiap kostrak di atas 0,5 sangat direkomendasikan dalam menguatkan hasil convergent validity.

\section{b.Discriminant Validity}

Evaluasi Discriminant validity dimulai dengan melihat cross loading. Nilai cross loading menunjukkan besarnya korelasi antara setiap konstrak dengan indikatornya dan indikator dari konstrak blok lainnya. Suatu model pengukuran memiliki Discriminant validity yang baik jika korelasi antara konstrak dengan indikatornya lebih tinggi daripada korelasi dengan indicator dari konstrak blok lain. Evaluasi selanjutnya dari discriminant validity adalah membandingkan nilai akar AVE dengan korelasi antar konstrak. Hasil yang direkomendasikan adalah bahwa nilai akar AVE harus lebih tinggi dari korelasi antar konstrak untuk mendapatkan nilai discriminant validity yang baik. Evaluasi model diskriminant validity selajutnya yaitu dengan melihat nilai composite reability dari blok indikator yang mengukur konstruk. Dalam evaluasi model diskriminant validity untuk semua nilai Composite Reliability pada setiap kostrak di atas 0,7 sangat direkomendasikan dalam menguatkan hasil discriminant validity. 
Keseluruhan pengukuran tersebut dapat dilakukan di SmartPLS 2 dengan memilih ikon Calculate dan meng-klik pilihan PLS Algorithm. Akan muncul berbagai macam hasil pengukuran, yang dapat digunakan sesuai dengan jenis indicator penelitian.

\section{Model Struktural atau InnerModel}

Inner model (inner relation, structural model dan substantive theory) menggambarkan hubungan antar variabel laten berdasarkan pada teori substantif. Model structural dievaluasi dengan menggunakan R-square untuk konstruk dependen dan uji t serta signifikansi dari koefisien parameter jalur struktural.

Dalam menilai model dengan PLS dimulai dengan melihat R-square untuk setiap variabel laten dependen. Interpretasinya sama dengan interpretasi pada regresi. Perubahan nilai R-square dapat digunakan untuk menilai pengaruh variabel laten terhadap variabel laten independen tertentu terhadap variabel laten dependen apakah mempunyai pengaruh yang substantif. Hasil R-square sebesar 0.67, 0.33 dan 0.19 untuk variabel laten endogen (variabel dependen) dalam model structural mengindikasikan bahwa model baik, moderat dan lemah. Dalam SmartPLS 2 hasil pengukuran nilai R-square dapat dihilat dari hasil PLS Algorithm.

Selain R-square, perlu juga dilakukan pengujian Q2 yang bertujuan untuk menguji apakah model yang digunakan mempunyai predictive relevance. Predictive relevance pada model struktural menunjukan seberapa baik nilai observasi yang dihasilkan dan juga estimasi parameternya. Pengujian ini seringkali disebut juga sebagai evaluasi goodness of fit.

$$
\begin{aligned}
& Q^{2}=1-\frac{\sum_{D} E_{D}}{\sum_{D} O_{D}} \\
& \text { Where, } \\
& \mathrm{E}=\text { The sum of squares of prediction error } \\
& \mathrm{O}=\text { The sum of squares error using the mean for prediction } \\
& \mathrm{D}=\text { Omission distance }
\end{aligned}
$$

Rumus diatas menunjukan rumus $\mathrm{Q}^{2}$ pada aplikasi SmartPLS. Pengujian $\mathrm{Q}^{2}$ dapat dilakukan dengan memilih icon Calculate pada SmartPLS kemudian meng-klik pilihan blindfolding, setelah muncul jendela pilih omission rentang antar 1 hingga 10 (pilih angka tertinggi sebelum warna merah muncul), selanjutnya setelah kalkulasi selesai pilih Construct Crossvalidated Redundancy. $\mathrm{Q}^{2}$ diterima apabila nilainya lebih besar dari 0 .

\section{Uji Hipotesis}

Jika nilai T-statistics lebih tinggi dibandingkan nilai T-table, berarti hipotesis diterima. Untuk tingkat keyakinan 95 persen (alpha 5 persen) maka nilai T-table untuk hipotesis satu ekor (one tailed) adalah $\geq 1,64$. Pengujian hipotesis dapat diformulasikan sebagai berikut:

H0: $\alpha 1 \leq 0$ : Menerima H0, jika t statistik $\leq 1,64$, artinya variabel independen tidak berpengaruh terhadap variabel dependen.

Ha: $\alpha 1=0$ : Menerima Ha, jika t statistik > 1,64, artinya variabel independen berpengaruh terhadap variabel dependen.

Dalam SmartPLS hasil pengujian hipotesis termasuk kedalam inner Model. Dapat diuji dengan cara memilih icon Calculate pada SmartPLS kemudian meng-klik 
pilihan bootstrapping. Selanjutnya pada pilih hasil laporan final result yang path coefficient. Maka muncul tabel yang menunjukan apakah hipotesis diterima atau ditolak.

\section{HASIL PENELITIAN Statistik Deskriptif}

Tabel 1. Hasil Uji Statistik Deskriptif

\begin{tabular}{|c|c|c|c|c|c|c|c|c|c|c|}
\hline pertanyaan & $\begin{array}{l}\text { sangat } \\
\text { setuju }\end{array}$ & $\%$ & setuju & $\%$ & $\begin{array}{l}\text { kurang } \\
\text { setuju }\end{array}$ & $\%$ & $\begin{array}{c}\text { tidak } \\
\text { setuju }\end{array}$ & $\%$ & $\begin{array}{c}\text { sangat } \\
\text { tidak } \\
\text { setuju }\end{array}$ & $\%$ \\
\hline X1LPQ1 & 13 & $27 \%$ & 18 & $38 \%$ & 14 & $29 \%$ & 2 & $2 \%$ & 1 & $2 \%$ \\
\hline X1LPQ2 & 6 & $13 \%$ & 31 & $65 \%$ & 9 & $19 \%$ & 2 & $4 \%$ & 0 & $0 \%$ \\
\hline X1LPQ3 & 0 & $0 \%$ & 32 & $67 \%$ & 13 & $27 \%$ & 3 & $6 \%$ & 0 & $0 \%$ \\
\hline X1PPQ1 & 11 & $23 \%$ & 19 & $40 \%$ & 15 & $31 \%$ & 3 & $6 \%$ & 0 & $0 \%$ \\
\hline X1PPQ2 & 10 & $21 \%$ & 24 & $50 \%$ & 11 & $23 \%$ & 3 & $6 \%$ & 0 & $0 \%$ \\
\hline X1PPQ3 & 11 & $23 \%$ & 23 & $48 \%$ & 11 & $23 \%$ & 3 & $6 \%$ & 0 & $0 \%$ \\
\hline X1PPQ4 & 11 & $23 \%$ & 21 & $44 \%$ & 15 & $31 \%$ & 1 & $2 \%$ & 0 & $0 \%$ \\
\hline X1PBKQ1 & 13 & $27 \%$ & 25 & $52 \%$ & 7 & $15 \%$ & 2 & $4 \%$ & 1 & $2 \%$ \\
\hline X1PBKQ2 & 14 & $29 \%$ & 22 & $46 \%$ & 8 & $17 \%$ & 4 & $8 \%$ & 0 & $0 \%$ \\
\hline $\mathrm{X} 2 \mathrm{Q} 1$ & 10 & $21 \%$ & 29 & $60 \%$ & 9 & $19 \%$ & 0 & $0 \%$ & 0 & $0 \%$ \\
\hline $\mathrm{x} 2 \mathrm{Q} 2$ & 9 & $19 \%$ & 28 & $58 \%$ & 10 & $21 \%$ & 1 & $2 \%$ & 0 & $0 \%$ \\
\hline $\mathrm{X} 2 \mathrm{Q3}_{3}$ & 6 & $13 \%$ & 27 & $56 \%$ & 13 & $27 \%$ & 2 & $4 \%$ & 0 & $0 \%$ \\
\hline YQ1 & 16 & $33 \%$ & 19 & $40 \%$ & 10 & $21 \%$ & 2 & $4 \%$ & 1 & $2 \%$ \\
\hline YQ2 & 10 & $21 \%$ & 25 & $52 \%$ & 10 & $21 \%$ & 3 & $6 \%$ & 0 & $0 \%$ \\
\hline YQ3 & 13 & $27 \%$ & 21 & $44 \%$ & 12 & $25 \%$ & 2 & $4 \%$ & 0 & $0 \%$ \\
\hline YQ4 & 13 & $27 \%$ & 23 & $48 \%$ & 10 & $21 \%$ & 1 & $2 \%$ & 1 & $2 \%$ \\
\hline
\end{tabular}

Berdasarkan tabel diatas sebagian besar jawaban responden untuk setiap pertanyaan adalah mengatakan setuju, sedangkan jawaban yang paling sedikit adalah sangat tidak setuju.

\section{Partial Least Square (PLS)}

Pengujian hipotesis dalam penelitian ini menggunakan metode Partial Least Square (PLS) dengan menggunakan software SmartPLS versi 2.0 M3. PLS merupakan metode alternative analisis dengan Structural Equation Modelling (SEM) yang berbasis varian. Keunggulan metode ini adalah tidak memerlukan asumsi dan dapat diestimasi dengan jumlah sampel yang relatif kecil.

Model struktural dalam penelitian ini ditampilkan pada Gambar 4.2. Gambar tersebut menunjukkan bahwa konstruk latar belakang pendidikan diukur dengan 3 indikator, konstruk pendidikan dan pelatihan diukur dengan 4 indikator, konstruk pengalaman bidang keuangan diukur dengan 2 indikator, konstruk tekanan eksternal diukur dengan 3 indikator dan konstruk kualitas laporan keuangan diukur dengan 4 indikator. Hubungan yang akan diteliti dilambangkan dengan anak panah antara konstruk yang terlihat pada Gambar 1. 


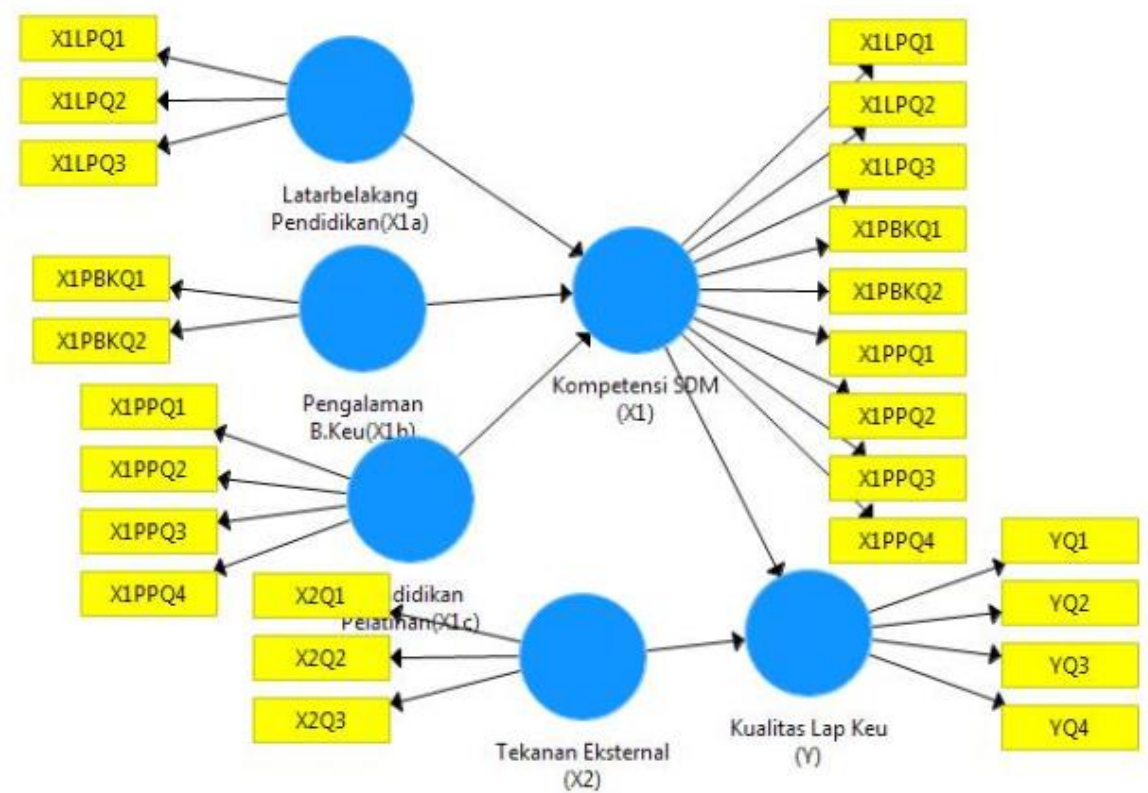

Gambar 1. Model Struktural

Dengan menggunakan SmartPLS 2.0 M3, kemudian model dieksekusi dengan menggunakan PLS Algorithm, yang menunjukan nilai outer model yang akan dijelaskan pada sub-bab berikut. Tampilan hasil PLS Algorithm dapat terlihat pada Gambar 2.

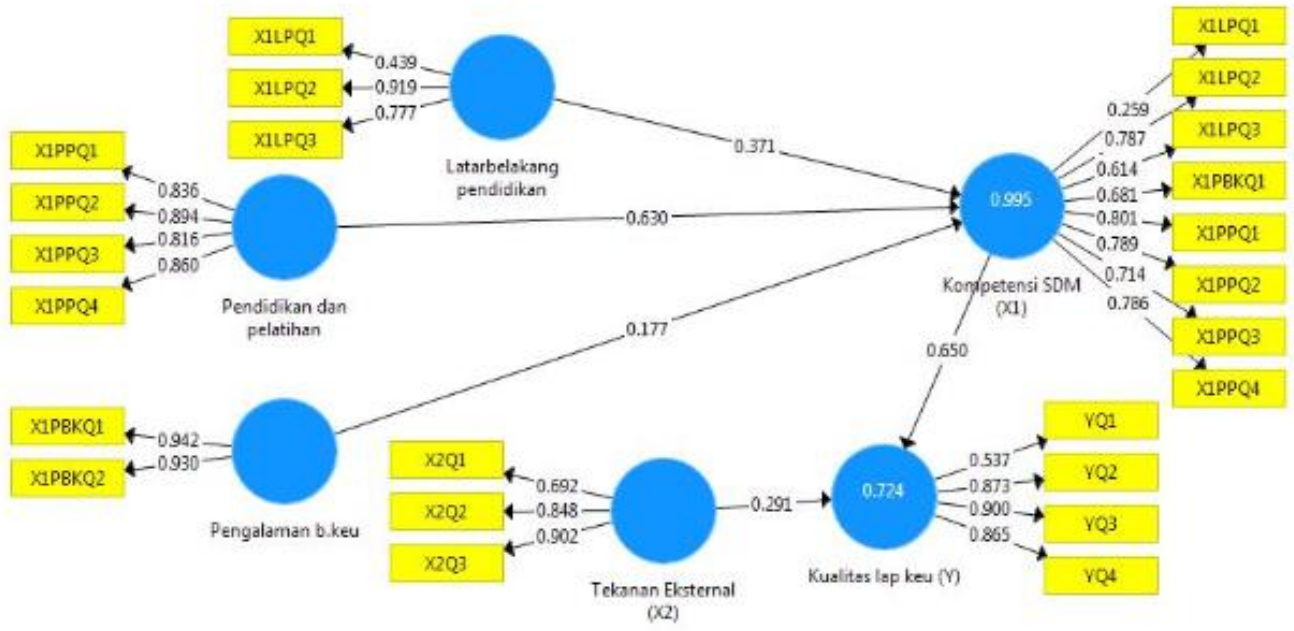

Gambar 2. PLS Algorithm

\section{Pengujian Model Pengukuran (Outer Model)}

Evaluasi awal model pengukuran ini bersifat reflektif, yaitu convergent validity dan discriminant validity. Evaluasi convergent validity dimulai dengan melihat item reliability (indikator validitas) yang ditunjukkan oleh nilai loading factor. Nilai loading factor kurang dari 0,5 akan dihilangkan dalam model. Evaluasi discriminant validity dimulai dengan melihat cross loading. Nilai cross loading menunjukkan besarnya korelasi antara setiap konstrak dengan indikatornya, dan indikator dari konstrak blok lainnya. Suatu model pengukuran memiliki discriminant validity yang baik bila bila korelasi antara konstrak dengan indikatornya lebih tinggi daripada korelasi indikator dari konstrak blok lainnya. 
1. Evaluasi konvergent validity

Tabel 2. Cross Loading

\begin{tabular}{|l|r|r|r|r|r|r|r|r|}
\hline & $\begin{array}{c}\text { Latar } \\
\text { belakang } \\
\text { pendidikan }\end{array}$ & $\begin{array}{c}\text { Pengalaman } \\
\text { b.keu }\end{array}$ & $\begin{array}{c}\text { Pendidikan } \\
\text { dan } \\
\text { pelatihan }\end{array}$ & $\begin{array}{c}\text { Kompetensi } \\
\text { SDM (X1) }\end{array}$ & $\begin{array}{c}\text { Tekanan } \\
\text { Eksternal } \\
\text { X2) }\end{array}$ & $\begin{array}{c}\text { Kualitas } \\
\text { lap keu } \\
\text { Y })\end{array}$ & $\begin{array}{c}\text { Convergent } \\
\text { validity }\end{array}$ & $\begin{array}{c}\text { Discriminant } \\
\text { validity }\end{array}$ \\
\hline X1LPQ1 & 0,439 & 0,161 & 0,075 & 0,259 & 0,011 & 0,322 & tidak valid & Baik \\
\hline X1LPQ2 & 0,919 & 0,560 & 0,545 & 0,787 & 0,337 & 0,743 & Valid & Baik \\
\hline X1LPQ3 & 0,777 & 0,506 & 0,398 & 0,614 & 0,379 & 0,492 & Valid & Baik \\
\hline X1PBKQ1 & 0,605 & 0,942 & 0,426 & 0,681 & 0,538 & 0,733 & Valid & Baik \\
\hline X1PBKQ2 & 0,522 & 0,930 & 0,455 & 0,620 & 0,523 & 0,684 & Valid & Baik \\
\hline X1PPQ1 & 0,552 & 0,419 & 0,836 & 0,801 & 0,436 & 0,566 & Valid & Baik \\
\hline X1PPQ2 & 0,457 & 0,362 & 0,894 & 0,789 & 0,406 & 0,520 & Valid & Baik \\
\hline X1PPQ3 & 0,342 & 0,408 & 0,816 & 0,714 & 0,542 & 0,459 & Valid & Baik \\
\hline X1PPQ4 & 0,436 & 0,412 & 0,860 & 0,786 & 0,411 & 0,635 & Valid & Baik \\
\hline X2Q1 & 0,266 & 0,379 & 0,364 & 0,388 & 0,692 & 0,378 & Valid & Baik \\
\hline X2Q2 & 0,305 & 0,413 & 0,468 & 0,485 & 0,848 & 0,596 & Valid & Baik \\
\hline X2Q3 & 0,361 & 0,586 & 0,448 & 0,521 & 0,902 & 0,614 & Valid & Baik \\
\hline YQ1 & 0,306 & 0,313 & 0,297 & 0,377 & 0,318 & 0,537 & Valid & Baik \\
\hline YQ2 & 0,684 & 0,640 & 0,499 & 0,695 & 0,618 & 0,873 & Valid & Baik \\
\hline YQ3 & 0,629 & 0,724 & 0,606 & 0,735 & 0,591 & 0,900 & Valid & Baik \\
\hline YQ4 & 0,683 & 0,685 & 0,612 & 0,755 & 0,559 & 0,865 & Valid & Baik \\
\hline
\end{tabular}

Berdasarkan hasil tabel di atas untuk semua nilai cross loading pada setiap kostrak di atas 0,5 artinya memiliki validitas yang dapat diterima. Dari semua indikator (item pertanyaan) terdapat satu indikator yang tidak valid dengan nilai yang tidak mencapai 0,5 yaitu X1LPQ1 sebesar 0,439. Sehingga dapat disimpulkan bahwa konstruk mempunyai convergent validity yang baik, dan komponen (item pertanyaan) (X1LPQ1) dikeluarkan dari model struktural.

Pemeriksaan selanjutnya dari convergent validity adalah dengan melihat nilai Average Variance Extracted (AVE). Tabel 3 berikut memperlihatkan hasil output AVE SmartPLS.

Tabel 3. Average Variance Extracted (AVE)

\begin{tabular}{|l|r|l|}
\hline & $\begin{array}{l}\text { Average } \\
\text { Variance } \\
\text { Extracted } \\
\text { (AVE) }\end{array}$ & \multicolumn{1}{|c|}{ Ket } \\
\hline Kompetensi SDM (X1) & 0,490 & $\begin{array}{l}\text { tidak } \\
\text { valid }\end{array}$ \\
\hline Kualitas lap keu (Y) & 0,652 & Valid \\
\hline Latar belakang pendidikan & 0,547 & Valid \\
\hline Pendidikan dan pelatihan & 0,726 & Valid \\
\hline Pengalaman b.keu & 0,876 & Valid \\
\hline Tekanan Eksternal (X2) & 0,671 & Valid \\
\hline \multicolumn{2}{|r|}{ Sumber : Pengolahan data dengan SmartPL , 2016 }
\end{tabular}

Berdasarkan tabel di atas untuk semua nilai AVE pada setiap kostrak di atas 0,5 sangat direkomendasikan dalam menguatkan hasil convergent validity. Dari semua konstrak terdapat satu konstrak yang tidak valid dengan nilai 0,490 yaitu kompetensi SDM. Sehingga dapat disimpulkan bahwa konstruk mempunyai convergent validity yang baik, dan komponen (item pertanyaan)(X1LPQ1) dikeluarkan dari model struktural.

\section{Evaluasi Discriminant Validity}

Nilai cross loading juga menunjukan adanya discriminate validity yang baik karena nilai korelasi indikator terhadap konstruk lebih tinggi dibandingkan dengan nilai korelasi indikator konstruk lainnya yang dapat dilihat pada Tabel 4.4 Cross 
Loading. Evaluasi selanjutnya dari discriminant validity adalah membandingkan antara nilai akar AVE dengan korelasi antar konstrak. Hasil yang direkomendasikan adalah bahwa nilai akar AVE harus lebih tinggi dari korelasi antar konstrak untuk mendapatkan nilai discriminant validity yang baik, seperti yang terlihat pada Tabel 4 dibawah ini:

Tabel 4. Akar AVE dan Korelasi Antar Konstruk

\begin{tabular}{|c|c|c|c|c|c|c|c|}
\hline & $\begin{array}{l}\text { Kompetensi } \\
\text { SDM (X1) }\end{array}$ & $\begin{array}{l}\text { Kualitas } \\
\text { lap keu } \\
\text { (Y) } \\
\end{array}$ & $\begin{array}{l}\text { Latar belakang } \\
\text { pendidikan }\end{array}$ & $\begin{array}{l}\text { Pendidikan } \\
\text { dan } \\
\text { pelatihan }\end{array}$ & $\begin{array}{l}\text { Pengalaman } \\
\text { b.keu }\end{array}$ & $\begin{array}{l}\text { Tekanan } \\
\text { Eksternal } \\
\text { (X2) }\end{array}$ & ket \\
\hline Kompetensi SDM (X1) & 1,000 & & & & & & baik \\
\hline Kualitas lap keu (Y) & 0,817 & 1,000 & & & & & baik \\
\hline Latar belakang pendidikan & 0,809 & 0,738 & 1,000 & & & & baik \\
\hline Pendidikan dan pelatihan & 0,908 & 0,642 & 0,527 & 1,000 & & & baik \\
\hline Pengalaman b.keu & 0,696 & 0,758 & 0,604 & 0,470 & 1,000 & & baik \\
\hline Tekanan Eksternal (X2) & 0,572 & 0,663 & 0,381 & 0,524 & 0,567 & 1,000 & baik \\
\hline
\end{tabular}

Berdasarkan tabel diatas nilai akar AVE untuk masing-masing konstrak lebih tinggi dari korelasi antar konstruk lain. Hal ini menunjukkan bahwa nilai discriminant validity baik, sehingga hasil evaluasi model ini sangat direkomendasikan.

Evaluasi model diskriminant validity selajutnya yaitu dengan melihat nilai composite reability dari blok indikator yang mengukur konstruk. Tabel 5 memperlihatkan hasil output composite reability smartPLS.

Tabel 5. Composite Reliability

\begin{tabular}{|l|r|c|}
\hline & $\begin{array}{r}\text { Composite } \\
\text { Reliability }\end{array}$ & Ket \\
\hline Kompetensi SDM (X1) & 0,879 & Baik \\
\hline Kualitas lap keu (Y) & 0,879 & Baik \\
\hline Latar belakang pendidikan & 0,770 & Baik \\
\hline Pendidikan dan pelatihan & 0,914 & Baik \\
\hline Pengalaman b.keu & 0,934 & Baik \\
\hline Tekanan Eksternal (X2) & 0,858 & Baik \\
\hline \multicolumn{2}{|l|}{ Sumber : Pengolahan data dengan SmartPLS, 2016 }
\end{tabular}

Dalam evaluasi model diskriminant validity untuk semua nilai Composite Reliability pada setiap kostrak di atas 0,7 sangat direkomendasikan dalam menguatkan hasil discriminant validity. Berdasarkan tabel dapat dilihat bahwasanya semua konstruk reliabel, karena composite reliability menunjukan nilai diatas 0.70.

\section{Pengujian Model Struktural (Inner Model)}

Setelah model yang diestimasi memenuhi kriteria discriminant validity berikutnya dilakukan pengujian model struktural (inner model). Menilai inner model adalah melihat hubungan antara konstruk laten dengan melihat hasil estimasi koefisien parameter path dan tingkat signifikansinya.

\section{Tabel 6. R-Square}

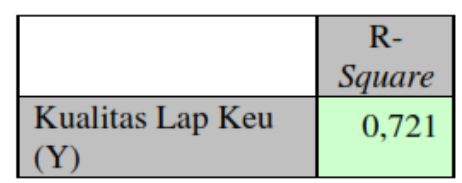

Sumber : Pengolahan data dengan SmartPLS, 2016

Tabel 6 menunjukkan bahwa nilai R-square konstrak kualitas laporan keuangan yaitu sebesar sebesar 72,1\%. Hal tersebut menandakan kompetensi SDM dan tekanan eksternal mampu menjelaskan kualitas laporan keuangan sebesar 72,1 \% yang masuk kedalam katagori baik, dan sisanya dijelaskan oleh variabel lain. Selanjutnya adalah evaluasi kekuatan prediksi model dari konstrak late eksogen dengan melihat nilai 
Stone-Geisser's $\mathrm{Q}^{2}$ (construct crossvalidated redundancry) dari output Smart PLS. Hasilnya adalah sebagai berikut :

Tabel 7. Q2 (Goodness of Fit)

\begin{tabular}{|l|r|r|r|}
\hline & SSO & SSE & $\begin{array}{l}\mathrm{Q}^{2}(=1- \\
\text { SSE/SSO) }\end{array}$ \\
\hline Kompetensi SDM (X1) & 384,000 & 218,948 & 0,430 \\
Kualitas lap keu (Y) & 192,000 & 111,331 & 0,420 \\
\hline Latar belakang pendidikan & 96,000 & 96,000 & \\
\hline Pendidikan dan pelatihan & 192,000 & 192,000 & \\
\hline Pengalaman b.keu & 96,000 & 96,000 & \\
\hline Tekanan Eksternal (X2) & 144,000 & 144,000 & \\
\hline
\end{tabular}

Sumber : Pengolahan data dengan SmartPLS, 2016

Pada tabel di atas, nilai $c v$ redundancry index untuk kompetensi SDM lebih besar dari 0 , yaitu 0.430 menunjukkan bahwa konstrak laten eksogen (Latar belakang pendidikan, Pengalaman B. Keuangan, Pendidikan Pelatihan memiliki predictive relevance yang baik untuk konstrak Kompetensi SDM. Begitu juga dengan nilai $\mathrm{cv}$ redundancry index untuk kualitas laporan keuangan yaitu 0.420 yang menunjukkan bahwa konstrak kompetensi SDM dan tekanan eksternal memiliki predictive relevance yang baik untuk konstrak kualitas laporan keuangan.

\section{HASIL UJI HIPOTESIS}

Dasar yang digunakan dalam menguji hipotesis adalah nilai yang terdapat pada hasil dari inner weight. Hipotesis diterima jika nilai T-statistic lebih besar dari T-tabel $(1,64)$ dan nilai $P$ value kecil dari 0,05 . Tabel berikut adalah hasil uji inner weight output smart PLS.

Tabel 8. Hasil dari Inner Weight

\begin{tabular}{|l|r|r|r|r|l|l|}
\hline & $\begin{array}{l}\text { Original } \\
\text { Sample } \\
(\mathrm{O})\end{array}$ & $\begin{array}{l}\text { Sample } \\
\text { Mean } \\
(\mathrm{M})\end{array}$ & $\begin{array}{l}\text { Standard } \\
\text { Deviation } \\
\text { (STDEV) }\end{array}$ & $\begin{array}{l}\text { T Statistics } \\
(\text { (|O/STDEV|) }\end{array}$ & $\begin{array}{l}\text { P } \\
\text { Values }\end{array}$ & ket \\
\hline $\begin{array}{l}\text { Kompetensi SDM (X1) -> Kualitas } \\
\text { laporan keuangan (Y) }\end{array}$ & 0,648 & 0,662 & 0,096 & 6,725 & 0,000 & $\begin{array}{l}\mathrm{H} 1 \\
\text { diterima }\end{array}$ \\
\hline $\begin{array}{l}\text { Tekanan Eksternal (X2) -> Kualitas } \\
\text { laporan keu (Y) }\end{array}$ & 0,291 & 0,275 & 0,114 & 2,560 & 0,011 & $\begin{array}{l}\mathrm{H} 2 \\
\text { diterima }\end{array}$ \\
\hline
\end{tabular}

Sumber : Pengolahan data dengan SmartPLS, 2016

Pada tabel di atas menunjukkan bahwa nilai koefisien beta/original sample dari hubungan kompetensi SDM terhadap kualitas laporan keuangan sebesar 0,648 $(64,8 \%)$ dan nilai $t$-statistic sebesar $6,725>t$-tabel 1,64 . Kemudian nilai $P$-values sebesar 0,000 (0\%) < 5\%. Hal tersebut menunjukan $\mathrm{H} 1$ diterima dengan tingkat keyakinan 100\%. Nilai koefisien beta/original sample dari hubungan tekanan eksternal terhadap kualitas laporan keuangan sebesar 0,291 (29,1 \%) dan nilai $t$-statistic sebesar $2,560<t$-tabel 1,64. Kemudian nilai $P$-values sebesar $0,011(1,1 \%)<5 \%$. Hal tersebut menunjukan $\mathrm{H} 2$ diterima dengan tingkat keyakinan $98,9 \%$. 


\section{PEMBAHASAN HASIL UJI HIPOTESIS}

Hubungan dan Pengaruh Antara Kompetensi Sumber Daya Manusia terhadap Kualitas Laporan Keuangan

Berdasarkan hasil perhitungan statistik, dapat disimpulkan bahwa konstruk kompetensi SDM berpengaruh positif terhadap kualitas laporan keuangan. Hasil penelitian ini konsisten dengan hasil penelitian Windiasatuti (2013); Ihsanti (2014); Nurillah (2014); Surastiani dan Handayani (2015); Andini dan Yusrawati (2015); Pradono dan Basukianto (2015) serta Wati dkk (2014) menyatakan bahwa Sumber Daya Manusia berpengaruh signifikan terhadap kualitas laporan keuangan.

Diterimanya hipotesis ini menunjukan bahwa kompetensi SDM di DPPKAD mempengaruhi kualitas laporan keuangan daerah. Hubungan posistif antar dua konstruk ini menunjukan bahwa semakin baik kompetensi yang dimiliki oleh sumber daya manusia pada DPPKAD dalam hal penyusunan laporan keuangan akan membuat laporan keuangan yang dihasilkan menjadi lebih baik. Hal ini dapat dilihat dari tingkat pendidikan, seringnya mengikuti pelatihan serta pengalaman pegawai di bidang keuangan.

Pendidikan adalah salah satu upaya dalam mengembangkan kompetensi sumber daya manusia terutama dalam pengembangan aspek intelektual dan kepribadian. Semakin tinggi tingkat pendidikan, maka semakin tinggi tingkat pengetahuan dan tingkat intelektualitas seseorang sehingga semakin berkompeten dalam penyusunan laporan keuangan. Berdasarkan data kuisioner yang ada sebagian besar PNS di DPPKAD adalah tamatan pendidikan tinggi dan berlatar pendidikan di bidang keuangan.

Selain latar belakang pendidikan, pegawai yang sering mengikuti program pendidikan dan pelatihan juga dapat mengembangkan dan meningkatkan pengetahuan, keterampilan dan kemampuan yang sudah dimilikinya agar semakin baik. Untuk menghasilkan laporan keuangan daerah yang baik dibutuhkan pegawai yang memahami betul cara dan proses dalam penyusunan laporan keuangan daerah. Berdasarkan data kuesioner yang ada, sebagian besar responden mengatakan sering mengikuti pendidikan dan pelatihan keuangan yang diadakan oleh DPPKAD. Pengalaman di bidang keuangan juga menunjukkan bahwa semakin lama pegawai bekerja dalam suatu bidang di organisasi, maka semakin banyak pengalaman pegawai tersebut dan semakin memahami apa yang menjadi tugas dan tanggungjawab yang diberikan kepada pegawai. Dalam menyusun laporan keuangan dibutuhkan pegawai yang benar-benar memahami akuntansi atau keuangan beserta aturan-aturan dalam penyusunan laporan keuangan daerah. Berdasarkan data kuesioner yang ada, sebagian besar responden mengatakan bahwa mereka memahami teori-teori yang berkaitan dengan keuangan serta memahami aturan dalam penyusunan laporan keuangan yang mengacu kepada Peraturan Pemerintah No 71 tahun 2010 tentang Standar Akuntansi Pemerintahan.

\section{Hubungan dan Pengaruh Antara Tekanan Eksternal terhadap Kualitas Laporan Keuangan}

Hipotesis 2 yang menyatakan tekanan eksternal berpengaruh positif terhadap kualitas laporan keuangan pemerintah daerah diterima. Hasil penelitian ini konsisten dengan hasil penelitian yang dilakukan oleh (Ridha dan Basuki, 2012) dan (Purnamasari dan Handayani, 2015) yang menyatakan bahwa tekanan eksternal berpengaruh signifikan terhadap transparansi pelaporan keuangan. Dengan diterimanya hipotesis ini menunjukkan bahwa adanya tekanan yang diberikan oleh 
pemerintah, peraturan dan lembaga lain dapat mempengaruhi kualitas laporan keuangan. Hubungan positif antara dua konstruk ini juga menunjukan bahwa semakin besar tekanan yang diberikan oleh pemerintah, peraturan dan lembaga lain maka semakin besar paksaan dan dorongan untuk melaksanakan proses pembuatan dan penyusunan laporan keuangan yang sesuai dengan semestinya sehingga laporan keuangan yang dihasilkan dapat memenuhi karakteristik kualitatif laporan keuangan yaitu andal, relevan, dapat dipahami serta dapat dibandingkan.

Dalam penyusunan dan pembuatan laporan keuangan pemerintah daerah diatur oleh Pemerintah dengan terbitnya undang-undang seperti Undang-Undang No.17 tentang Keuangan Negara dan No.32 tahun 2004 tentang Pemerintah daerah, serta adanya peraturan dari pemerintah yang mengatur tentang Peraturan Standar Akuntansi Pemerintahan (PSAP) yang terdapat dalam PP 71 tahun 2010. Berdasarkan hasil pemeriksaan BPK, Laporan Hasil Pemeriksaan Laporan Keuangan Pemerintah Daerah (LHP-LKPD) tahun anggaran 2015, Sawahlunto mendapatkan opini tertinggi berupa Wajar Tanpa Pengecualian (WTP). Pada tahun-tahun sebelumnya Pemerintah Daerah Kota Sawahlunto hanya mendapatkan opini Wajar Dengan Pengecualian (WDP). Untuk (LHP-LKPD) tahun anggaran 2015 Pemda Sawahlunto dituntut dengan system akrual basis berdasarkan PP 71 tahun 2010. Selain itu Pemda Sawahlunto juga memperoleh arahan dari BPK perwakilan Sumbar dalam membenahi manajemen aset. Hal ini membuktikan bahwa aturan dan tuntutan dari Pemerintah mempengaruhi kualitas laporan keuangan. Berdasarkan data kuisioner yang ada, sebagian besar pegawai DPPKAD juga menyatakan dorongan dari pemerintah, pihak investor atau komunitas bisnis serta masyarakat dalam meningkatkan kualitas laporan keuangan.

\section{KESIMPULAN}

Penelitian ini bertujuan untuk menganalisis faktor-faktor yang mempengaruhi kualitas laporan keuangan pemerintah daerah. Adapun variabel yang digunakan dalam penelitian ini adalah kompetensi sumber daya manusia yang didukung oleh latar belakang pendidikan keuangan; pendidikan dan pelatihan; pengalaman bidang keuangan, tekanan eksternal, serta kualitas laporan keuangan. Penelitian ini menggunakan Partial Least Square (PLS) dalam menganalisis hubungan antara variabel. Berdasarkan analisis dan pembahasan pada bagian sebelumnya, maka dapat ditarik kesimpulan sebagai berikut:

1. Kompetensi SDM berpengaruh terhadap kualitas laporan keuangan. Hal ini menunjukan bahwa semakin baik kompetensi yang dimiliki oleh sumber daya manusia pada DPPKAD dalam hal penyusunan laporan keuangan akan membuat laporan keuangan yang dihasilkan menjadi lebih baik yang sesuai dengan Karakteristik kualitatif laporan keuangan yaitu relevan, andal, dapat dibandingkan, serta dapat dipahami.

2. Tekanan eksternal berpengaruh terhadap kualitas laporan keuangan pemerintah daerah diterima. Hal ini menunjukan bahwa semakin besar tekanan yang diberikan oleh pemerintah, peraturan dan lembaga lain maka semakin besar paksaan dan dorongan untuk melaksanakan proses pembuatan dan penyusunan laporan keuangan yang sesuai dengan semestinya sehingga laporan keuangan yang dihasilkan dapat memenuhi karakteristik kualitatif laporan keuangan yaitu andal, relevan, dapat dipahami serta dapat dibandingkan. 
3. Kompetensi SDM dan tekanan eksternal merupakan konstruk yang mempengaruhi penggunaan senyatanya, dengan tingkat persentase sebesar $72,1 \%$

\section{SARAN}

Adapun saran-saran yang dapat diberikan sehubungan dengan penelitian yang telah dilakukan adalah sebagai berikut:

1. Berdasarkan keterbatasan dalam penelitian ini, diharapkan terdapat penelitian dengan topik serupa yang dilakukan kembali untuk menyempurnakan dan memperkuat hasil penelitian ini dengan menambahkan variabel variabel lainnya yang belum termasuk dalam penelitian ini.

2. Selain itu penelitian selanjutnya diharapkan dapat memperluas objek penelitian sehingga akan didapatkan hasil penelitian yang lebih signifikan..

\section{DAFTAR REFERENSI}

Andini, D. dan Yusrawati. 2015. Pengaruh Kompetensi Sumber Daya Manusia dan Penerapan Sistem Akuntansi Keuangan Daerah terhadap Kualitas Laporan Keuangan Daerah. Pada SKPD Kabupaten Empat Lawang Sumatra Selatan. Jurnal Ekonomi, Manajemen dan Akuntansi, Vol.24 No.1. 2015.

Ashwort, R., G.Boyne., dan R.Delbridge. 2009. Escape from the Iron Cage? Organizational Change and Isomorphic Pressures in the Public Sector. Journal of public Administration Research and Theory.

A. W. Wijaya. 1990, Administrasi Kepegawaian Suatu Pengantar, Edisi II. Cetakan 2. Jakarta: CV Rajawali Pers.

Budiawan. D. A. 2014. Pengaruh Sistem Pengendalian Internal dan Kekuatan Koersif terhadap Kualitas Laporan Keuangan Pemerintah Daerah. Universitas Pendidikan Indonesia.

Halmawati dan Mustin. A. F. 2015. Penerapan Transparansi Pelaporan Keuangan Dalam Perspektif Tekanan Eksternal dan Komitmen Organisasi. SNEMA 2015. Universitas Negeri Padang.

Ihsanti,E. 2014. Pengaruh Kompetensi Sumber Daya Manusia dan Penerapan Sistem Akuntansi Keuangan Daerah terhadap Kualitas Laporan Keuangan Daerah. Studi Empiris pada Kabupaten Lima Puluh Kota. Artikel. Universitas Negeri Padang. Padang.

Indriantoro,N dan Supomo. B. 2011. "Metodologi Penelitian Bisnis untuk Akuntansi dan Manajemen". Edisi Pertama. Yogyakarta: BPFE.

Marwansyah. 2014. "Manajemen Sumber Daya Manusia”. Bandung: Edisi Kedua. Alfabeta. CV.

Nurillah,A. S. 2014. Pengaruh Kompetensi Sumber Daya Manusia, Penerapan Sistem Akuntansi Keuangan Daerah (SAKD), Pemanfaatan teknologi Informasi, dan Sistem Pengendalian Intern terhadap Kualitas Laporan Keuangan Pemerintah Daerah. Studi Empiris pada SKPD Kota Depok. Skripsi. Universitas Diponegoro. Semarang.

Padek. 2016. "13 Tahun Menanti, Sawahlunto Raih WTP". Padang Ekspres. 17 Juni 2016. Peraturan Pemerintah Nomor 58 Tahun 2005 Tentang Pengelolaan Keuangan Daerah Peraturan Pemerintah Nomor 71 Tahun 2010 tentang Standar Akuntansi Pemerintahan.

Permadi,A. 2013. Pengaruh Penerapan Sistem Akuntansi Keuangan Pemerintah Daerah Terhadap Kualitas Laporan Keuangan Pemerintah Daerah. Studi Kasus Pada Dinas Bima Marga Provinsi Jawa Barat. Skripsi. Universitas Widyatama. 
Pradono, C. Basukianto. 2015. Kualitas Laporan Keuangan Pemerintah Daerah: Faktor yang Mempengaruhi dan Implementasi Kebijakan. Studi pada SKPD Pemerintah Provinsi Jawa Tengah. Jurnal Bisnis dan Ekonomi (JBE). Vol. 22 No. 2. 2015.

Purnamasari,W dan Handayani,N. 2015. Pengaruh Sumber Daya Manusia, Tekanan Eksternal, Komitmen Manajemen terhadap Transparansi Pelaporan Keuangan. Jurnal Ilmu dan Riset Akuntansi.Vol. 4 No. 2. 2015.

Pusat Bahasa Departemen Pendidikan Nasional. 2002. Kamus Besar Bahasa Indonesia. Jakarta: Balai Pustaka.

Ridha. A. M dan Basuki. H. 2012. Pengaruh Tekanan Eksternal, Ketidakpastian Lingkungan Dan Komitmen Management Terhadap Penerapan Transparansi Pelaporan Keuangan.

Soekidjo Notoatmodjo. 2003. Pendidikan dan Perilaku Kesehatan. Jakarta: PT. Rineka Cipta.

Sondang P. Siagian. 1992. Manajemen Sumber Daya Manusia. Jakarta: Bumi Aksara.

Sukmaningrum,T. 2012. Analisis Faktor-Faktor yang Mempengaruhi Kualitas Informasi Laporan Keuangan Pemerintah Daerah. Studi Empiris pada Pemerintah Kabupaten dan Kota Semarang. Skripsi. Universitas Diponegoro. Semarang.

Surastiani,D. Handayani,B. P. 2015. Analisis Faktor-Faktor yang mempengaruhi Kualitas Informasi Laporan Keuangan Pemerintah Daerah. Jurnal Dinamika Akuntansi. Vol. 7. No. 2. 2015.

Syarifudin,A. 2014. Pengaruh Kompetensi SDM dan Peran Audit Intern terhadap Kualitas Laporan Keuangan Pemerintah Daerah dengan Variabel Intervening Sistem Pengendalian Internal Pemerintah. Studi Empiris pada Pemkab Kebumen. Jurnal Fokus Bisnis. Volume 14. No 02. 2014.

Undang-undang No 33 Tahun 2004 tentang Perimbangan Keuangan Antara Pemerintah Pusat dan Pemerintah Daerah.

Undang-undang Republik Indonesia Nomor 20 Tahun 2003 Tentang Sistem Pendidikan Nasional.

Wati,K, Herawati,N. dan Sinarwati,N. 2014. Pengaruh Kompetensi SDM, Penerapan SAP, dan Sistem Akuntansi Keuangan Daerah terhadap Kualitas Laporan Keuangan Daerah. E-Journal S1 Ak. Universitas Pendidikan Ganesha.Vol. 2. No. 1. 2014.

Windiastuti,R. 2013. Pengaruh Sumber Daya Manusia Bidang Akuntansi Dan Sistem Pengendalian Internal Terhadap Kualitas Laporan Keuangan Pemerintah Daerah. Studi Kasus Pada Dinas Pengelolaan Keuangan Dan Aset Daerah Kota Bandung. Skripsi. Universitas Widyatama. Bandung.

Yamin.S dan Kurniawan. H. 2011. Partial Least Square Path Modeling. Jakarta: Salemba Empat. 